\title{
Impact of intercontinental pollution transport on North American ozone air pollution: an HTAP phase 2 multi-model study
}

\author{
Min Huang ${ }^{1,2}$, Gregory R. Carmichael ${ }^{3}$, R. Bradley Pierce ${ }^{4}$, Duseong S. Jo ${ }^{5}$, Rokjin J. Park ${ }^{5}$, Johannes Flemming ${ }^{6}$, \\ Louisa K. Emmons ${ }^{7}$, Kevin W. Bowman ${ }^{8}$, Daven K. Henze ${ }^{9}$, Yanko Davila ${ }^{9}$, Kengo Sudo ${ }^{10}$, Jan Eiof Jonson ${ }^{11}$, \\ Marianne Tronstad Lund ${ }^{12}$, Greet Janssens-Maenhout ${ }^{13}$, Frank J. Dentener ${ }^{13}$, Terry J. Keating ${ }^{14}$, Hilke Oetjen ${ }^{8, a}$, \\ and Vivienne H. Payne ${ }^{8}$ \\ ${ }^{1}$ George Mason University, Fairfax, VA, USA \\ ${ }^{2}$ University of Maryland, College Park, MD, USA \\ ${ }^{3}$ University of Iowa, Iowa City, IA, USA \\ ${ }^{4}$ NOAA National Environmental Satellite, Data, and Information Service, Madison, WI, USA \\ ${ }^{5}$ Seoul National University, Seoul, South Korea \\ ${ }^{6}$ European Centre for Medium-Range Weather Forecasts, Reading, UK \\ ${ }^{7}$ National Center for Atmospheric Research, Boulder, CO, USA \\ ${ }^{8}$ Jet Propulsion Laboratory, California Institute of Technology, Pasadena, CA, USA \\ ${ }^{9}$ University of Colorado Boulder, Boulder, CO, USA \\ ${ }^{10}$ Nagoya University, Furo-cho, Chikusa-ku, Nagoya, Japan \\ ${ }^{11}$ Norwegian Meteorological Institute, Oslo, Norway \\ ${ }^{12}$ Center for International Climate and Environmental Research, Oslo, Norway \\ ${ }^{13}$ European Commission, Joint Research Centre, Ispra, Italy \\ ${ }^{14}$ US Environmental Protection Agency, Washington, DC, USA \\ ${ }^{a}$ now at: University of Leicester, Leicester, UK
}

Correspondence to: Min Huang (mhuang10@gmu.edu)

Received: 27 October 2016 - Discussion started: 28 November 2016

Revised: 10 April 2017 - Accepted: 10 April 2017 - Published: 8 May 2017

\begin{abstract}
The recent update on the US National Ambient Air Quality Standards (NAAQS) of the ground-level ozone $\left(\mathrm{O}_{3}\right)$ can benefit from a better understanding of its source contributions in different US regions during recent years. In the Hemispheric Transport of Air Pollution experiment phase 1 (HTAP1), various global models were used to determine the $\mathrm{O}_{3}$ source-receptor (SR) relationships among three continents in the Northern Hemisphere in 2001. In support of the HTAP phase 2 (HTAP2) experiment that studies more recent years and involves higher-resolution global models and regional models' participation, we conduct a number of regional-scale Sulfur Transport and dEposition Model (STEM) air quality base and sensitivity simulations over North America during May-June 2010. STEM's top and lateral chemical boundary conditions were downscaled from three global chemical transport models' (i.e., GEOS-Chem,
\end{abstract}

RAQMS, and ECMWF C-IFS) base and sensitivity simulations in which the East Asian (EAS) anthropogenic emissions were reduced by $20 \%$. The mean differences between STEM surface $\mathrm{O}_{3}$ sensitivities to the emission changes and its corresponding boundary condition model's are smaller than those among its boundary condition models, in terms of the regional/period-mean $(<10 \%)$ and the spatial distributions. An additional STEM simulation was performed in which the boundary conditions were downscaled from a RAQMS (Realtime Air Quality Modeling System) simulation without EAS anthropogenic emissions. The scalability of $\mathrm{O}_{3}$ sensitivities to the size of the emission perturbation is spatially varying, and the full (i.e., based on a $100 \%$ emission reduction) source contribution obtained from linearly scaling the North American mean $\mathrm{O}_{3}$ sensitivities to a $20 \%$ reduction in the EAS anthropogenic emissions may be un- 
derestimated by at least $10 \%$. The three boundary condition models' mean $\mathrm{O}_{3}$ sensitivities to the $20 \%$ EAS emission perturbations are $\sim 8 \%$ (May-June 2010)/ 11\% (2010 annual) lower than those estimated by eight global models, and the multi-model ensemble estimates are higher than the HTAP1 reported 2001 conditions. GEOS-Chem sensitivities indicate that the EAS anthropogenic $\mathrm{NO}_{x}$ emissions matter more than the other EAS $\mathrm{O}_{3}$ precursors to the North American $\mathrm{O}_{3}$, qualitatively consistent with previous adjoint sensitivity calculations.

In addition to the analyses on large spatial-temporal scales relative to the HTAP1, we also show results on subcontinental and event scales that are more relevant to the US air quality management. The EAS pollution impacts are weaker during observed $\mathrm{O}_{3}$ exceedances than on all days in most US regions except over some high-terrain western US ru$\mathrm{ral} / \mathrm{remote}$ areas. Satellite $\mathrm{O}_{3}$ (TES, JPL-IASI, and AIRS) and carbon monoxide (TES and AIRS) products, along with surface measurements and model calculations, show that during certain episodes stratospheric $\mathrm{O}_{3}$ intrusions and the transported EAS pollution influenced $\mathrm{O}_{3}$ in the western and the eastern US differently. Free-running (i.e., without chemical data assimilation) global models underpredicted the transported background $\mathrm{O}_{3}$ during these episodes, posing difficulties for STEM to accurately simulate the surface $\mathrm{O}_{3}$ and its source contribution. Although we effectively improved the modeled $\mathrm{O}_{3}$ by incorporating satellite $\mathrm{O}_{3}$ (OMI and MLS) and evaluated the quality of the HTAP2 emission inventory with the Royal Netherlands Meteorological Institute-Ozone Monitoring Instrument (KNMI-OMI) nitrogen dioxide, using observations to evaluate and improve $\mathrm{O}_{3}$ source attribution still remains to be further explored.

\section{Introduction}

Tropospheric ozone $\left(\mathrm{O}_{3}\right)$, a short-lived trace gas with a lifetime ranging from hours in the boundary layer to weeks in the free troposphere, affects tropospheric chemistry, harms human and ecosystem health, and induces climate change on local, regional, and global scales (Jerrett et al., 2009; Smith et al., 2009; Anenberg et al., 2010; Mauzerall and Wang, 2001; Avnery et al., 2011a, b; Shindell et al., 2009, 2013; Bowman and Henze, 2012; Stevenson et al., 2006, 2013; Monks et al., 2015). It has been recognized that the uneven distributions of tropospheric $\mathrm{O}_{3}$ can be attributed to the stratosphere as well as local, regional, and distant emission sources, through complicated processes that occur on synoptic and meso- and micro-scales (Task Force on Hemispheric Transport of Air Pollution (HTAP), 2010; National Research Council, 2009; Maas and Grennfelt, 2016). The mitigation of $\mathrm{O}_{3}$ 's climate and health impacts would benefit from efforts to control the emissions of its precursors from the various emission sources (United Nations Environment Programme and World Meteo- rological Organization 2011), such as nitrogen oxides $\left(\mathrm{NO}_{x}\right)$, carbon monoxide $(\mathrm{CO})$, methane $\left(\mathrm{CH}_{4}\right)$, and non-methane volatile organic compounds (NMVOCs).

Ground-level $\mathrm{O}_{3}$ is one of the six criteria air pollutants regulated by the US Environmental Protection Agency (EPA), and the US National Ambient Air Quality Standards (NAAQS) have recently been lowered to $70 \mathrm{ppbv}$ to better protect Americans' health and the environment. Issues regarding making accurate estimates of the total $\mathrm{O}_{3}$ as well as the background $\mathrm{O}_{3}$ level, defined as the concentration that is not affected by recent locally emitted or produced anthropogenic pollution (e.g., McDonald-Buller et al., 2011; Zhang et al., 2011; Fiore et al., 2014; Huang et al., 2015), have been recently discussed as part of the implementation of the new $\mathrm{US}_{3}$ standard (US EPA, 2016a, b). This includes assessing the impacts of various components of the background $\mathrm{O}_{3}$, such as stratospheric $\mathrm{O}_{3}$, local natural sources such as biogenic, lightning, and wildfire emissions, and the longrange transport (LRT) of pollution. The impact of the transPacific pollution transport on US air quality has been evaluated in numerous studies over the past decades (e.g., Fiore et al., 2009; Reidmiller et al., 2009; Zhang et al., 2008, 2009; Huang et al., 2010, 2013a; Lin et al., 2012a, 2015, 2017; US EPA, 2016a). It has been found that the increasing trends of pollution in the upwind continents, especially the populated East Asia (e.g., Zhang et al., 2014; Susaya et al., 2013; Wang et al., 2012), may partially offset the US air quality improvements in recent decades due to the regional and local emission controls (e.g., Jacob et al., 1999; Verstraeten et al., 2015; Ambrose et al., 2011; Wigder et al., 2013; Cooper et al., 2010; Parrish et al., 2009, 2012; Gratz et al., 2014). A better understanding of the processes that determine the $\mathrm{O}_{3}$ pollution levels, as well as an improved capability of attributing the air pollution to nearby or distant sources, is needed to assist with designing and implementing effective local emission control strategies to comply with the tighter air quality standards.

Chemical transport models are often used to reproduce and attribute the observed $\mathrm{O}_{3}$ levels, including assessing the impacts of the internationally transported $\mathrm{O}_{3}$ on the US air quality. In the HTAP modeling experiment phase 1 (HTAP1), various global models with horizontal resolutions ranging from $1^{\circ} \times 1^{\circ}$ to $5^{\circ} \times 5^{\circ}$, only around half of which are finer than $3^{\circ} \times 3^{\circ}$, were used to determine the $\mathrm{O}_{3}$ sourcereceptor (SR) relationships among three continents in the Northern Hemisphere in 2001 (Chapter 4 in HTAP, 2010). The global-model-based SR relationships in HTAP1 determined using the emission perturbation approach (i.e., calculating the changes of $\mathrm{O}_{3}$ at the receptor regions in response to a $20 \%$ reduction in the emission inputs in a given source region) were reported as either monthly $24 \mathrm{~h}$ mean values or policy-relevant metrics such as the maximum daily $8 \mathrm{~h}$ average (MDA8) for the US (e.g., Fiore et al., 2009; Reidmiller et al., 2009). Large intermodel diversity was found in the simulated total $\mathrm{O}_{3}$ and the intercontinentally transported pollution 
for the chosen SR pairs in the northern midlatitudes, indicating the challenges with model simulations to accurately represent the key atmospheric processes. Multi-model mean results were the foci in these studies, with the assumption that this approach can reduce the uncertainty from the single model estimates for monthly or seasonal means. "Ensemble" model analyses have been suggested by some US stakeholders as one of the methods for helping with the characterization of the background $\mathrm{O}_{3}$ components (US EPA, 2016b). Although the multi-model approach can help identify some of the weaknesses of the individual models and may produce more reliable estimates, it is necessary to well understand the uncertainties inherent in using the same set of anthropogenic emissions in all these model simulations. Satellite observations over the regions with limited in situ measurements such as East Asia can be particularly helpful for quantifying such uncertainties.

The $20 \%$ emission perturbation in the HTAP1 modeling experiment was chosen to produce a sizeable (i.e., larger than numerical noise) and realistic impact but small enough in the assumed near-linear atmospheric chemistry regime. The scalability of the modeled $\mathrm{O}_{3}$ sensitivities to the size of the emission perturbations has been assessed on continental scale (Wu et al., 2009; Fiore et al., 2009; HTAP, 2010; Wild et al., 2012; Emmons et al., 2012). The receptor $\mathrm{O}_{3}$ responses to the source-region emission perturbations are found to be fairly linear within $\sim 50 \%$ of the perturbations. However, due to the chemical nonlinearity, the full source contribution obtained by linearly scaling the receptor regional-mean $\mathrm{O}_{3}$ sensitivity to the $20 \%$ reduction in the source region emissions may be underestimated and the scalability depended on seasons and the perturbed emission species. Huang et al. (2013b) investigated the scalability of the $\mathrm{O}_{3}$ sensitivity between the southern California-US intermountain west SR pair for May 2010, in which study the southern California anthropogenic emissions were perturbed by multiple amounts of $+50,-50$, and $-100 \%$. They reported that the scalability of the $\mathrm{O}_{3}$ sensitivities changed with the distance from the source regions. Further analyses on the scalability of these modeled $\mathrm{O}_{3}$ sensitivities during recent years especially for the East Asia-NAM (North America) SR pair, as well as their spatial variability, are still needed. Furthermore, results generated using the emission perturbation approach need to be compared with those based on the other methods (e.g., tagged tracers and adjoint sensitivity).

Previous studies have demonstrated the advantages of high-resolution chemical transport modeling for understanding SR relationships (e.g., Lin et al., 2010, for Europe and East Asia; Lin et al., 2012a; Huang et al., 2010, 2013a for Asia and NAM). Using observations (satellite, sondes, and aircraft) along with single model simulations, a few studies have reported that the $\mathrm{US} \mathrm{O}_{3}$ sensitivities to extra-regional sources is time- and region-dependent (e.g., Lin et al., 2012a, b; Langford et al., 2011; Ott et al., 2016), and therefore the necessity of evaluating the extra-regional source impacts on event scale has been emphasized in these studies as well as in US EPA $(2016 a, b)$. The HTAP phase 2 (HTAP2) multimodel experiment, initiated in 2012, is designed to advance the understanding of the impact of intercontinental pollution transport during more recent years (i.e., 2008-2010), involving a number of global and regional models' participation (Galmarini et al., 2017; Koffi et al., 2016). The regional models are anticipated to help connect the analyses over global and regional scales and enable discussions on small spatial (e.g., subcontinental) and temporal scales (i.e., event based analyses). The use of satellite products for identifying the transport events as well as for quantitative model evaluation is also encouraged in the work plan. The HTAP2 modeling experiment was sequentially conducted in two steps. First, similar to the HTAP1 experiment, a group of global models with different resolutions conducted base and emission perturbation sensitivity simulations to determine the pollutants' SR relationships. All models in their base simulations used the same set of harmonized sector-based global anthropogenic emissions developed specifically for the HTAP2 modeling experiment (Janssens-Maenhout et al., 2015). Most of these global models recorded only key chemical species from their base and sensitivity simulations in varied temporal frequencies. Several global models saved the threedimensional (3-D) chemical fields of more species with a 3 or $6 \mathrm{~h}$ interval, which are suitable for being used as regional models' chemical boundary conditions. In the second step, regional models conducted base and sensitivity simulations to analyze the pollutants' SR relationships in greater detail. The regional model simulations used the same set of anthropogenic emissions as the global models within their simulation domains, and the chemical boundary conditions in these regional simulations were downscaled from the base and sensitivity simulations from the selected boundary condition model outputs. For regional simulations over the North America and Europe, boundary conditions were mostly taken from a single model such as the ECMWF C-IFS or GEOSChem.

This study aims to address (1) the comparison of the $\mathrm{O}_{3}$ sensitivities generated from the HTAP2 and HTAP1 experiments, which could help address how the LRT impacts on NAM changed through time; (2) how the refined modeling experiment design in HTAP2 can help advance our understanding of the LRT impacts on NAM, particularly the involvement of regional models and the inclusion of small spatial-temporal scale analyses during high $\mathrm{O}_{3}$ episodes that are more relevant to air quality management; and (3) the usefulness of satellite observations for better understanding the sources of uncertainties in the modeled total $\mathrm{O}_{3}$ (e.g., from the emission and regional models' boundary condition inputs) as well as for reducing the uncertainties in some of these model inputs via chemical data assimilation. We performed a number of regional-scale STEM (Sulfur Transport and dEposition Model) base and sensitivity simulations over NAM during May-June 2010, during which 
period strong trans-Pacific pollution transports were shown to episodically impact the US (Lin et al., 2012a). Extending the HTAP2 regional simulations' basic setup, the STEM top and lateral chemical boundary conditions were downscaled from three global models' (i.e., the Seoul National University (SNU)-GEOS-Chem, RAQMS, and the ECMWF C-IFS) base and sensitivity simulations in which the East Asian anthropogenic emissions were reduced. The STEM surface $\mathrm{O}_{3}$ sensitivities over the NAM region based on different boundary condition models were intercompared in terms of the regional averages and the spatial patterns on monthly basis and during a selected event identified by satellite $\mathrm{O}_{3}$ and $\mathrm{CO}$ products. These were also compared with the sensitivities estimated by their corresponding boundary condition models as well as all HTAP2 participating global models and the results from HTAP1.

\section{Methods}

\subsection{Anthropogenic emission inputs}

Identical anthropogenic emissions were used in all global and regional chemical transport models' base and sensitivity simulations. This monthly varying harmonized sectoral (i.e., power, industry, transportation, residential, shipping, aircraft, and agriculture) emission inventory was provided on a gridded $0.1^{\circ} \times 0.1^{\circ}$ resolution for the years of 2008 and 2010, by compiling the officially reported emissions at the national scale (Janssens-Maenhout et al., 2015; http://edgar.jrc.ec.europa.eu/htap_v2). The temporal profiles for developing the monthly varying emissions differ by region and sector. The amount of emissions of key $\mathrm{O}_{3}$ precursors (CO, $\mathrm{NO}_{x}$, and NMVOCs) from both years are summarized in Table S1 in the Supplement for the four major emissions sectors, over NAM (US + Canada, based on data from the US EPA and the Environmental Canada, which shows lower emissions from the previous years as also discussed in Pouliot et al., 2015), the Model Inter-Comparison Study for Asia (MICS-Asia) regions (South, Southeast, and East Asia, based on country inventory for China and from the Clean Air Policy Support System and the Regional Emission inventory in ASia 2.1, more information also in Li et al., 2017), and for over the world. For all of these species, global total emissions in 2008 and 2010 are similar. The $\mathrm{NO}_{x}$, NMVOC, and CO emissions decreased from 2008 to 2010 over NAM by $10.7,9.4$, and $15.7 \%$, respectively. In 2008, NAM NO , NMVOC, and CO contributed to $18.0,11.7$, and $11.9 \%$ of the global total, respectively, and in 2010 these contributions became $15.8,10.5$, and $10.2 \%$. For 2010 , the transportation sector contributed more than the other sectors to NAM anthropogenic $\mathrm{NO}_{x}$ and $\mathrm{CO}$ emissions; the industrial sector contributed more than the other sectors to NMVOCs emissions. Over East Asian countries, these emissions are $\sim 2-5$ times higher than the US emissions, and the $\mathrm{NO}_{x}$,
NMVOC, and CO emissions increased over Asia by 7.3, 7.2 , and $1.0 \%$, with the dominant emission sectors in 2010 of transportation, industry, and residential, respectively. For both years, the emissions over the MICS-Asia regions contribute to over $40 \%$ of the global emissions. For these key $\mathrm{O}_{3}$ precursors, the East Asian countries contribute to $45 \%$ (NMVOCs) $-70 \%\left(\mathrm{NO}_{x}\right)$ of the emissions in the MICS-Asia domain in both years, and the South Asian countries contribute to $\sim 22 \%\left(\mathrm{NO}_{x}\right)-34 \%$ (NMVOCs) of the MICS-Asia emissions. The uncertainty of the emission estimates differs by emission sector and species: i.e., the emissions from largescale combustion sources (e.g., $\mathrm{NO}_{x}$ and $\mathrm{CO}$ from power and industry sectors) are less uncertain than those from smallscale and scattered sources (e.g., CO and NMVOCs from transportation and residential sources). Non-anthropogenic emission inputs used in different models' simulations may differ, and their impacts on the modeled total $\mathrm{O}_{3}$ and the SR relationships will be compared in detail in future studies.

\subsection{Region definitions for the SR study and the model base and sensitivity simulations}

\subsubsection{Base and $20 \%$ emission perturbation simulations from global and regional models}

The HTAP2 simulations from eight global models, used in this study, are listed in Table 1a, including the relevant references. Horizontal and vertical resolutions of these models range from finer than $1^{\circ}$ to coarser than $2.5^{\circ}$ and from 20 to 60 layers, respectively. Overall these resolutions are higher than the HTAP1 participating models'. Figure 1 defines the source regions used in the HTAP2 SR relationship study, and we will focus in this study on assessing the East Asia (EAS), South Asia (SAS), Europe (EUR), and non-NAM anthropogenic source (interchangeable in this paper with "(all) foreign") impacts on the NAM $\mathrm{O}_{3}$ levels in 2010. Specifically, each model performed a base simulation and a number of sensitivity simulations in which the original HTAP2 anthropogenic emissions for all species and sectors in a defined source region were perturbed by a certain amount (referring to $20 \%$ as in most cases), and these cases are defined in Table $1 \mathrm{a}-\mathrm{b}$ as [source region]ALL[perturbation (\%)], where "ALL" refers to "all species and sectors", consistent with HTAP1 and HTAP2's naming convention. The $\mathrm{O}_{3}$ differences $R\left(\mathrm{O}_{3}\right.$, [source region], [perturbation (\%)]) over NAM were then calculated between each model's base and sensitivity simulations:

$$
\begin{aligned}
& R\left(\mathrm{O}_{3}, \text { EAS, } 20 \%\right)= \\
& \quad \text { BASE } \mathrm{O}_{3}-\text { EASALL }(-20 \%) \mathrm{O}_{3}, \\
& R\left(\mathrm{O}_{3}, \mathrm{SAS}, 20 \%\right)= \\
& \quad \text { BASE } \mathrm{O}_{3}-\operatorname{SASALL}(-20 \%) \mathrm{O}_{3},
\end{aligned}
$$


Table 1. (a) HTAP2 base and sensitivity simulations by various global models. (b) STEM regional simulations for HTAP2. (c) STEM and its boundary condition models' key inputs and chemical mechanisms, with references. More details on the models can be found in (a) and the text.

\begin{tabular}{|c|c|c|c|c|c|c|c|}
\hline $\begin{array}{l}\text { (a) Global model, resolution: } \\
\text { lon } \times \text { lat } \times \text { vertical layer, } \\
(\text { References })\end{array}$ & BASE & $\begin{array}{c}\text { EASALL } \\
(-20 \%)\end{array}$ & $\begin{array}{l}\text { EASALL } \\
(-100 \%)\end{array}$ & $\begin{array}{l}\text { GLOALL } \\
(-20 \%)\end{array}$ & $\begin{array}{c}\text { NAMALL } \\
(-20 \%)\end{array}$ & $\begin{array}{c}\text { EURALL } \\
(-20 \%)\end{array}$ & $\begin{array}{c}\text { SASALL } \\
(-20 \%)\end{array}$ \\
\hline $\begin{array}{l}\text { CAM-Chem, } \\
2.5^{\circ} \times 1.9^{\circ} \times 56 \\
\text { (Tilmes et al., 2016) }\end{array}$ & $\checkmark$ & $\checkmark$ & & $\checkmark$ & $\checkmark$ & $\checkmark$ & $\checkmark$ \\
\hline $\begin{array}{l}\text { CHASER T42, } \\
\sim 2.8^{\circ} \times 2.8^{\circ} \times 32 \\
(\text { Sudo et al., 2002) }\end{array}$ & $\checkmark$ & $\checkmark$ & & $\checkmark$ & $\checkmark$ & $\checkmark$ & $\checkmark$ \\
\hline $\begin{array}{l}\text { EMEP rv } 48, \\
0.5^{\circ} \times 0.5^{\circ} \times 20 \\
(\text { Simpson et al., 2012) }\end{array}$ & $\checkmark$ & $\checkmark$ & & $\checkmark$ & $\checkmark$ & $\checkmark$ & $\checkmark$ \\
\hline $\begin{array}{l}\text { SNU-GEOS-Chem v9-01-03, } \\
2.5^{\circ} \times 2^{\circ} \times 47 \\
\text { (Park et al., 2004; http://iek8wikis.iek. } \\
\text { fz-juelich.de/HTAPWiki/WP2.3?action= } \\
\text { AttachFile\&do=view\&target=_README_ } \\
\text { GEOS-Chem.pdf) }\end{array}$ & $\checkmark$ & $\checkmark$ & & $\checkmark$ & $\checkmark$ & & \\
\hline $\begin{array}{l}\text { CU-Boulder GEOS-Chem adjoint v35f, } \\
2.5^{\circ} \times 2^{\circ} \times 47 \\
(\text { Henze et al., 2007) }\end{array}$ & $\checkmark$ & $\checkmark$ & & $\checkmark$ & $\checkmark$ & $\checkmark$ & $\checkmark$ \\
\hline $\begin{array}{l}\text { RAQMS, } \\
1^{\circ} \times 1^{\circ} \times 35 \\
\text { free running } \\
\text { (Pierce et al., 2007, 2009) }\end{array}$ & $\checkmark$ & $\checkmark$ & $\checkmark$ & & & & \\
\hline $\begin{array}{l}\text { RAQMS, } \\
1^{\circ} \times 1^{\circ} \times 35, \\
\text { with satellite assimilation } \\
\text { (Pierce et al., 2007, 2009) }\end{array}$ & $\checkmark$ & & & & & & \\
\hline $\begin{array}{l}\text { OsloCTM3 v2, } \\
\sim 2.8^{\circ} \times 2.8^{\circ} \times 60 \\
(\text { Søvde et al., 2012) }\end{array}$ & $\checkmark$ & $\checkmark$ & & $\checkmark$ & $\checkmark$ & $\checkmark$ & $\checkmark$ \\
\hline $\begin{array}{l}\text { ECMWF C-IFS, } \\
\sim 0.7^{\circ} \times 0.7^{\circ} \times 54 / 1.125^{\circ} \times 1.125^{\circ} \times 54 \\
(\text { Flemming et al., 2015) }\end{array}$ & $\checkmark$ & $\checkmark$ & & $\checkmark$ & $\checkmark$ & $\checkmark$ & $\checkmark$ \\
\hline
\end{tabular}

\begin{tabular}{lccc}
\hline $\begin{array}{l}\text { (b) Boundary condition model, } \\
\text { resolution: lon } \times \text { lat } \times \text { vertical layer }\end{array}$ & BASE & $\begin{array}{c}\text { EASALL } \\
(-20 \%)\end{array}$ & $\begin{array}{c}\text { EASALL } \\
(-100 \%)\end{array}$ \\
\hline SNU-GEOS-Chem v9-01-03, $2.5^{\circ} \times 2^{\circ} \times 47$ & $\checkmark$ & $\checkmark$ & $\checkmark$ \\
RAQMS, $1^{\circ} \times 1^{\circ} \times 35$, free running & $\checkmark$ & $\checkmark$ & \\
RAQMS, $1^{\circ} \times 1^{\circ} \times 35$, with satellite assimilation & $\checkmark$ & & \\
ECMWF C-IFS, $1.125^{\circ} \times 1.125^{\circ} \times 54$ & $\checkmark$ & $\checkmark$ \\
\hline
\end{tabular}


Table 1. Continued.

\begin{tabular}{lllll}
\hline (c) Model & Meteorology & Biogenic VOCs; $\mathrm{NO}_{x}$ & Lightning & $\mathrm{B}$ \\
\hline GEOS-Chem & GEOS-5 & MEGAN v2.1 (Guen- & based on GEOS-5 deep & G \\
& & ther et al., 2012; Wang & convective cloud top & al., \\
& et al., 2009) & $\begin{array}{l}\text { heights and climatologi- } \\
\text { cal observations (Murray } \\
\end{array}$ & & et al., 2012)
\end{tabular}

RAQMS Online (Pierce et al., 2007)

Biomass burning

GFED v3.0 (van der Werf et

al., 2010)

logi- 

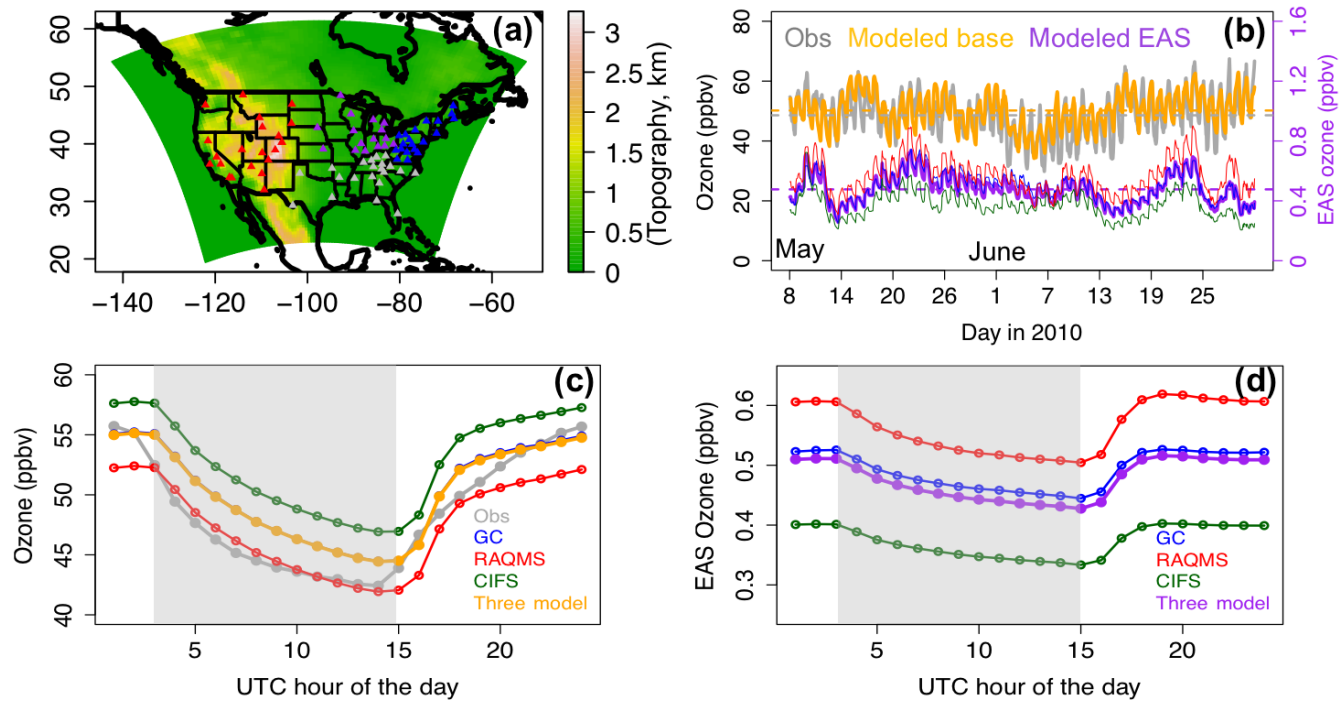

Figure 2. (a) The $60 \mathrm{~km}$ STEM NAM domain, colored by the model topography. The CASTNET sites to evaluate $\mathrm{O}_{3}$ from the STEM base simulations are marked as triangles in different colors that identify the subregions they belong to (red: western US; gray: southern US; purple: the Midwest; blue: northeastern US). (b) Evaluation of the STEM-modeled (averaged from the three base simulations using the GEOS-Chem, ECMWF C-IFS, and RAQMS base runs as the chemical boundary conditions) hourly $\mathrm{O}_{3}$ at the western US (i.e., EPA regions 8, 9, and 10) CASTNET sites. Observations, modeled base $\mathrm{O}_{3}$, and the modeled $R\left(\mathrm{O}_{3}\right.$, EAS, $\left.20 \%\right)$ are in gray, orange, and purple lines, respectively. The horizontal dashed lines indicate the period-mean values. The $R\left(\mathrm{O}_{3}\right.$, EAS, $\left.20 \%\right)$ values from STEM calculations using three different chemical boundary conditions are shown separately in thin lines (blue: GEOS-Chem; red: RAQMS; green: C-IFS). The period-mean diurnal variability of the STEM-modeled (c) base and (d) $R\left(\mathrm{O}_{3}\right.$, EAS, $\left.20 \%\right)$ at the western US CASTNET sites. The STEM calculations using three different chemical boundary conditions are shown separately as well as averagely. Light gray-shaded areas indicate the local standard nighttime (from 06:00/07:00 p.m. to 07:00/08:00 a.m.).

The denominator and numerator terms of RERER represent the impacts of global and non-NAM anthropogenic emissions on $\mathrm{NAM} \mathrm{O}_{3}$, respectively. The higher the NAM RERER value is, the stronger the impact from non-local sources on NAM is indicated. The RERER value can exceed 1 when emission reductions lead to increasing concentrations (e.g., $\mathrm{O}_{3}$ titration by nitrogen monoxide, $\mathrm{NO}$ ).

The STEM (version 2K3) regional simulations were then performed on a $60 \mathrm{~km} \times 60 \mathrm{~km}$ horizontal-resolution (a typical coarse regional model resolution) grid over NAM within the domain defined in Fig. 2a during May-June 2010. The meteorological conditions in spring 2010 were compared with the climatology from the NCEP/NCAR reanalysis data for the 1981-2010 period (Kalnay et al., 1996) in Huang et al. (2013b), concluding that this spring represents a period of stronger-than-climatological average spring trans-Pacific transport, based on a stronger meridional gradient of sea level pressure in the North Pacific and higher Pacific/North American (PNA) indexes. This is consistent with the findings by Lin et al. (2014) that the El Niño conditions during the 2009/2010 winter strengthened the trans-Pacific transport of Asian pollution in spring 2010. The mean near-surface air temperatures in the western US in this spring were lower than the climatology, with larger anomalies in the mountain states, which may have led to weaker local $\mathrm{O}_{3}$ production and decomposition of the transported peroxyacyl nitrates. In contrast, higher-than-normal temperatures were found in the eastern US that favored anomalously strong local $\mathrm{O}_{3}$ production.

STEM has been used to interpret the observations collected by satellites and during aircraft campaigns in the past decade (e.g., Carmichael et al., 2003a, b; Huang et al., 2010, 2013a, b, 2014, 2015). STEM calculates gas-phase chemistry reactions based on the SAPRC 99 gaseous chemical mechanism (Carter, 2000) with thirty photolysis rates calculated online by the Tropospheric Ultraviolet and Visible radiation model (Madronich et al., 2002). Most of the key configurations of the $60 \mathrm{~km}$ base simulations are the same as those described in Lapina et al. (2014), i.e., meteorological fields were pre-calculated by the Advanced Research Weather Research and Forecasting Model (WRF-ARW; Skamarock et al., 2008) version 3.3.1 forced by the North American Regional Reanalysis data (Mesinger et al., 2006), using a similar set of the physics configuration to those in Huang et al. (2013a). Biomass burning emissions are from the Fire INventory from NCAR (FINN) version 1.0 (Wiedinmyer et al., 2011). Biogenic emissions were calculated by the Model of Emissions of Gases and Aerosols from Nature (MEGAN) version 2.1 (Guenther et al., 2012), driven by the WRF meteorology. Lightning $\mathrm{NO}_{x}$ emissions are generated following the method in Allen et al. (2012), with the flash rates determined by the WRF convective precipi- 
tation and scaled to the National Lightning Detection Network flash rates. A major difference of the STEM simulations in this study from the Lapina et al. (2014) study is that the anthropogenic emissions were replaced with the monthly mean HTAP2 inventory with no weekday-weekend variability applied, rather than the earlier National Emissions Inventory (NEI) 2005 in which the weekday-weekend variability exists. This change can introduce uncertainty for some US regions where weekday-weekend variability of some $\mathrm{O}_{3}$ precursors' emissions was notable during the studied period (e.g., weekend $\mathrm{NO}_{x}$ emissions in southern California during CalNex 2010 were $0.6-0.7$ of the weekday emissions as reported by Kim et al., 2016, and Brioude et al., 2013), but this was done to ensure consistency with the HTAP2 global model simulations, which also did not use daily variable emissions for any regions in the world. The VOC speciation for the SAPRC 99 chemical mechanism in the NEI 2005 (ftp: //aftp.fsl.noaa.gov/divisions/taq/emissions_data_2005) were applied to break down the total NMVOC emissions provided in the HTAP2 inventory. The VOC speciation based on the year of 2005 can be unrealistic for 2005 and 2010, as studies have reported variable temporal changes of different VOC species in some US cities (e.g., Warneke et al., 2012). The time-varying lateral and top boundary conditions in the STEM base simulations were downscaled from three global models' (i.e., 3-hourly SNU-GEOS-Chem, 3-hourly ECMWF C-IFS, and 6-hourly RAQMS) base simulations. In support of the SR relationship study to quantify the East Asia anthropogenic impacts on NAM, three STEM sensitivity simulations were also conducted in which the STEM boundary conditions were downscaled from the EASALL $(-20 \%)$ sensitivity simulations by these three global models (Table 1b). All STEM-simulated 3-D chemical fields were saved hourly for the convenience of calculating the US primary $\mathrm{O}_{3}$ standard metric MDA8 as well as the quantitative comparisons against the satellite Level 2 (L2) $\mathrm{O}_{3}$ products. The STEM base case surface $\mathrm{O}_{3}$ performance and its $\mathrm{O}_{3}$ sensitivities were also compared with those of its boundary condition models as well as the multi-global model means. The latitude/longitude ranges $\left(20-50^{\circ} \mathrm{N} / 130-65^{\circ} \mathrm{W}\right)$ of NAM for the global and regional-model-based sensitivity calculations were selected to mainly account for the coverage of the STEM domain, which are slightly different from the definition of North America in HTAP1.

Note that non-anthropogenic emission inputs used in STEM and its boundary condition models differed, as summarized in Table 1c. Figure S1 in the Supplement shows detailed comparisons between STEM and GEOS-Chem's non-anthropogenic (i.e., soil, lightning, and biomass burning) $\mathrm{NO}_{x}$ emission inputs, and their impacts on the modeled NAM background $\mathrm{O}_{3}$ were included in Lapina et al. (2014). Such quantitative comparisons will also be carried out between STEM and its other boundary condition models in future studies.

\subsubsection{Additional base and sensitivity simulations from selected models}

In addition to the base and 20\% EAS all-category emission perturbation simulations, the global RAQMS model conducted a sensitivity simulation in which the East Asian anthropogenic emissions were zeroed out, which was also used as STEM's boundary conditions (Table $1 \mathrm{~b}$ ). We calculate the " $\mathrm{S}_{3}$ " metric (Eq. 3) using the $\mathrm{O}_{3}$ sensitivities in STEM and RAQMS at the receptor regions in response to both 20 and $100 \%$ of emission reductions to explore the relationships between the $\mathrm{O}_{3}$ sensitivity and the size of the emission perturbation. A closer-to-one $S_{\mathrm{O}_{3}}$ value indicates higher scalability of the sensitivity based on the $20 \%$ emission perturbation method for obtaining the full "contribution" of the East Asian anthropogenic emissions on the $\mathrm{NAM} \mathrm{O}_{3}$.

$S_{\mathrm{O}_{3}}=R\left(\mathrm{O}_{3}\right.$, EAS, $\left.100 \%\right) / R\left(\mathrm{O}_{3}\right.$, EAS, $\left.20 \%\right) / 5$,

where $R\left(\mathrm{O}_{3}, \quad\right.$ EAS, $\left.100 \%\right)=\mathrm{BASE} \quad \mathrm{O}_{3}-$ EASALL $(-100 \%) \mathrm{O}_{3}$.

The RAQMS model also provided a base simulation that assimilated satellite $\mathrm{O}_{3}$ products from the Ozone Monitoring Instrument (OMI; Levelt et al., 2006) and Microwave Limb Sounder (MLS; Livesey et al., 2008; Pierce et al., 2007), which was used to help better understand the regional model base run error sources as well as for demonstrating the use of satellite observations to help improve the representation of the trans-boundary pollution.

We also used a number of sensitivity simulations produced by the GEOS-Chem adjoint model v35f in which the emissions from selected anthropogenic emission sectors (power and industry, transportation, residential) or individual $\mathrm{O}_{3}$ precursor chemical species $\left(\mathrm{NO}_{x}, \mathrm{VOC}, \mathrm{CO}\right)$ over East Asia were reduced by $20 \%$. Additional simulations for the 2008 2009 periods by the SNU-GEOS-Chem were also utilized to quantify the East Asia and non-NAM anthropogenic source impacts in comparison to the 2010 conditions that we mainly focus on in this study.

\subsection{In situ and satellite observations}

\subsubsection{In situ observations}

Over the NAM receptor, the hourly $\mathrm{O}_{3}$ observations at the Clean Air Status and Trends Network (CASTNET, http:// epa.gov/castnet/javaweb/index.html) sites were used to evaluate the global and regional models' base simulations in four subregions: western US (i.e., the EPA regions 8, 9, and 10); southern US (i.e., the EPA regions 4 and 6), the Midwest (i.e., the EPA regions 5 and 7), and the northeast (i.e., the EPA regions 1-3). The numbers of sites used in global and regional models' evaluation in each US subregion are summarized in Tables 2 and 3. The locations of these sites and the subregions they belong to are indicated in Fig. 2a, overlaid on a model-based terrain height map. A majority of the CAST- 
Table 2. (a) Evaluation of the period-mean (1 May-30 June 2010) multi-global model free simulations against the CASTNET observations, only at the sites where $95 \%$ of the hourly $\mathrm{O}_{3}$ observations are available. Evaluation of the individual models is summarized in (b). (b) Evaluation of the period-mean (May-June 2010) global model free simulations against the EANET and CASTNET observations. The STEM boundary condition models are highlighted in bold. (c) Evaluation of the period-mean (May-June 2010) multi-global model free simulations against the EANET observations in Japan and South Korea. Evaluation of the individual models is summarized in (b).

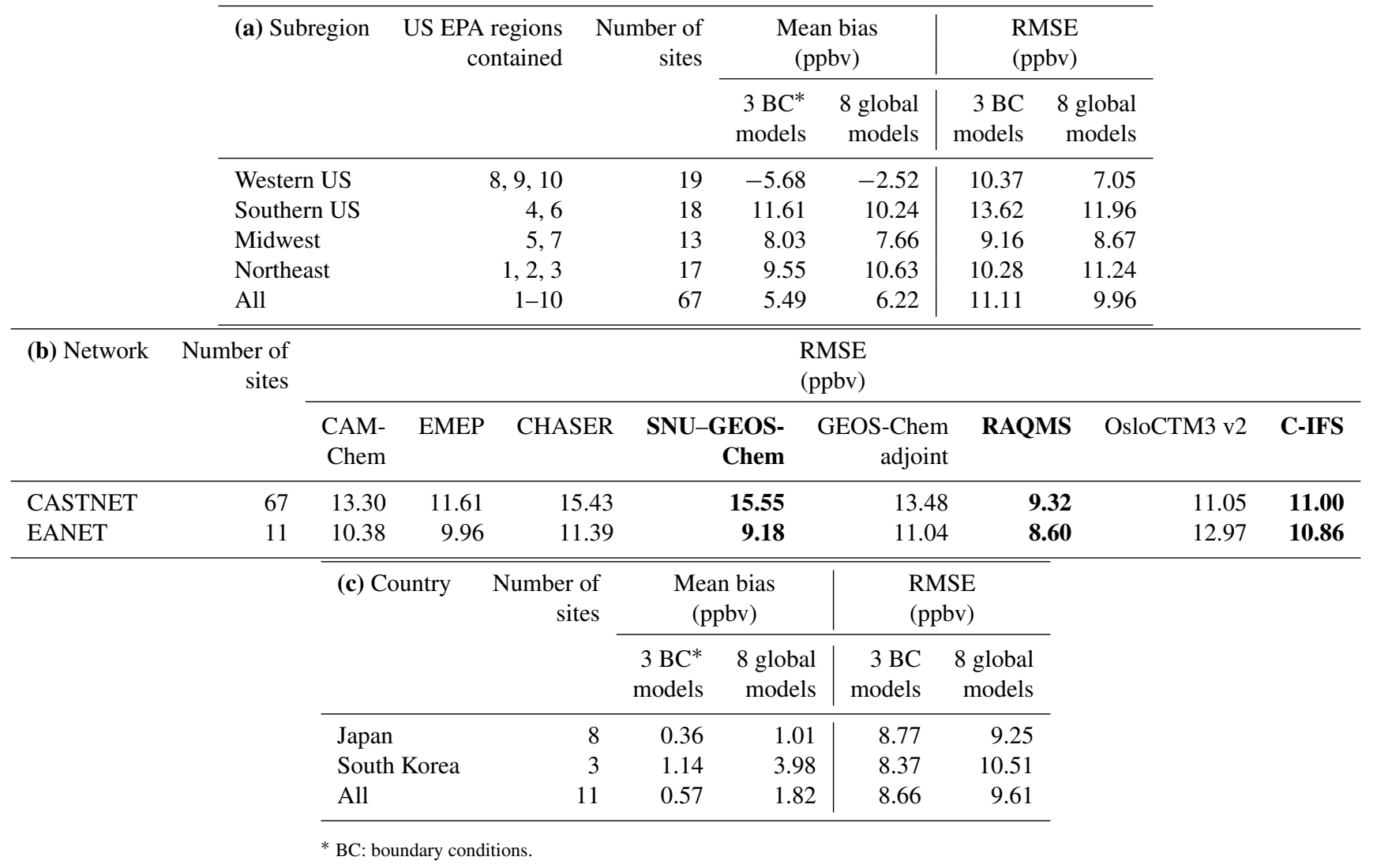

NET sites in the western US are located at high-elevation $(>1 \mathrm{~km})$ remote or rural regions, which are more susceptible to the trans-boundary pollution (e.g., Jaffe, 2011). Most of the sites in the other three subregions are located in low elevation regions, mainly affected by local and regional pollution. The model-based terrain heights represent the reality on subregional scale fairly well - the differences between the actual and model-based subregional-mean terrain heights at the CASTNET sites are smaller than $0.1 \mathrm{~km}$ (Table 3).

During May-June 2010, intense ozonesonde measurements were made at multiple California locations (Cooper et al., 2011), in support of the NOAA California Research at the Nexus of Air Quality and Climate Change (CalNex) field experiment (Ryerson et al., 2013). They have been used to evaluate the simulated $\mathrm{O}_{3}$ vertical profiles by the HTAP2 participating models. The detailed evaluation results have been shown by Cooper (2016) and will be covered by subsequent publications.

Over HTAP2's EAS source region, the global models' $\mathrm{O}_{3}$ performance was evaluated against the monthly mean surface in situ $\mathrm{O}_{3}$ measurements at 11 sites within the Acid
Deposition Monitoring Network in East Asia (EANET, http: //www.eanet.asia) that had data throughout the year of 2010. These include eight Japanese and three South Korean sites (Fig. 3a), all of which are located at low elevation regions $(2-150 \mathrm{~m})$. The reported monthly mean observations at these sites were based on weekly or daily sampled data, varying among sites.

\subsubsection{Satellite products}

In two case studies of high $\mathrm{O}_{3}$ episodes, $\mathrm{L} 2$ and $\mathrm{L} 3 \mathrm{O}_{3}$ and $\mathrm{CO}$ retrievals from several satellite instruments were used to assess the impacts of trans-Pacific pollution transport and stratospheric $\mathrm{O}_{3}$ intrusions on NAM $\mathrm{O}_{3}$ levels in early May. These include (1) the early afternoon $\mathrm{O}_{3}$ and $\mathrm{CO}$ profiles version 5 from the Tropospheric Emission Spectrometer (TES; Beer et al., 2001; Beer, 2006) on the Aura satellite; (2) the mid-morning $\mathrm{O}_{3}$ profiles from the METOP-Infrared Atmospheric Sounding Interferometer (IASI), which were retrieved using the Jet Propulsion Laboratory (JPL) TES optimal estimation retrieval algorithm (Bowman et al., 2006) 

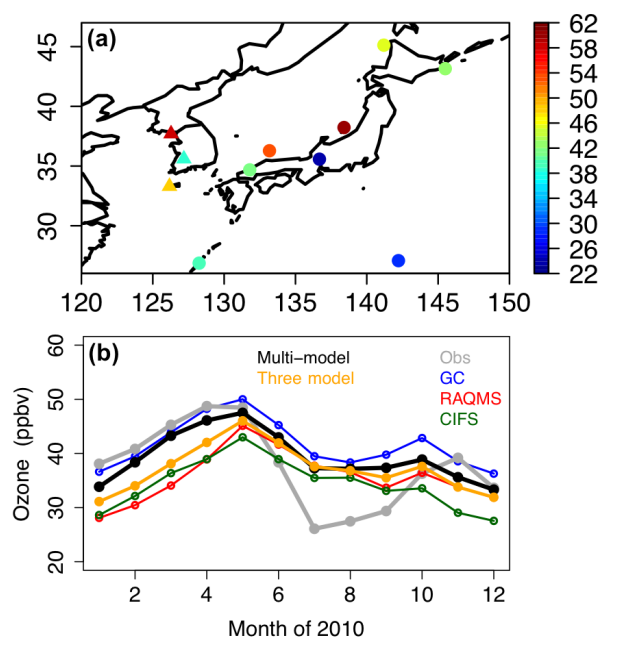

Figure 3. (a) May-June 2010 period-mean surface $\mathrm{O}_{3}$ observations in ppbv at eight Japanese (filled circles) and three South Korean (filled triangles) EANET sites. (b) Observed and modeled monthly mean surface $\mathrm{O}_{3}$ in 2010 at all eleven EANET sites. The "Multimodel" and "Three model" in the legend indicate the mean values of all eight global models and only of the three boundary condition models, respectively.

for selected areas including the western US (Oetjen et al., 2014, 2016); and (3) the early afternoon $\mathrm{L}_{3} \mathrm{O}_{3}$ and $\mathrm{CO}$ maps (version $6,1^{\circ} \times 1^{\circ}$ ) from the Aqua Atmospheric Infrared Sounder (AIRS) instrument. The TES tropospheric $\mathrm{O}_{3}$ retrieval is often sensitive to the mid- to lower free troposphere, and $\mathrm{O}_{3}$ at these altitudes in the eastern Pacific is known to possibly impact the downwind US surface air quality at later times (Huang et al., 2010; Parrish et al., 2010). TES $\mathrm{O}_{3}$ is generally positively biased by $<15 \%$ relative to high accuracy/precision reference datasets (e.g., Verstraeten et al., 2013). Although IASI is in general less sensitive than TES due to its coarse spectral resolution, the $681-316 \mathrm{hPa}$ partial column-averaged $\mathrm{O}_{3}$ mixing ratios in the JPL product agree well with $\mathrm{TES} \mathrm{O}_{3}$ for the 2008-2011 period with a $-3.9 \mathrm{ppbv}$ offset (Oetjen et al., 2016). Note that $\mathrm{IASI} \mathrm{O}_{3}$ data are processed operationally in Europe using a different algorithm. For this work we used $\mathrm{O}_{3}$ profiles from TES and IASI processed using a consistent algorithm at JPL, although the latter set of data represents only a small subset of the full set of the IASI radiance measurements. The IASI and TES $\mathrm{L}_{2} \mathrm{O}_{3}$ profiles (screened by the retrieval quality and the $\mathrm{C}$-curve flags) were used to evaluate the STEM O $\mathrm{O}_{3}$ vertical distributions in the different base simulations, and the satellite observation operators were applied in these comparisons. Taking TES as an example, its observation operator $\boldsymbol{h}_{z}$ for $\mathrm{O}_{3}$ is written in Eq. (4):

$\boldsymbol{h}_{z}=\boldsymbol{z}_{\mathrm{c}}+\mathbf{A}_{\mathrm{TES}}\left(\ln \left(\mathbf{F}_{\mathrm{TES}}(\boldsymbol{c})\right)-\boldsymbol{z}_{\mathrm{c}}\right)$

where $z_{\mathrm{c}}$ is the natural log form of the TES constraint vector (a priori) in volume mixing ratio. $\mathbf{A}_{\mathrm{TES}}$ is the averaging kernel matrix reflecting the sensitivity of retrieval to changes in the true state (Rodgers, 2000). $\mathbf{F}_{\mathrm{TES}}$ projects the modeled $\mathrm{O}_{3}$ concentration fields $\boldsymbol{c}$ to the TES grid using spatial and temporal interpolation. The exponent of $\boldsymbol{h}_{z}$ is then used to compute the mismatches between the model and TES $\mathrm{O}_{3}$ retrievals as the model evaluation. A small mismatch between model with the satellite observation operators and the satellite retrievals may indicate either good model performance or may be the low sensitivity of the retrievals to the true $\mathrm{O}_{3}$ profile. AIRS $\mathrm{O}_{3}$ is sensitive to the altitudes near the tropopause, with positive biases over the ozonesondes in the upper troposphere (e.g., Bian et al., 2007); AIRS CO is most sensitive to $300-600 \mathrm{hPa}$ (Warner et al., 2007) and is frequently used together with the AIRS $\mathrm{O}_{3}$ to distinguish the stratospheric $\mathrm{O}_{3}$ intrusions from long-range transported anthropogenic or biomass burning pollution. We use the L3 AIRS products in this study to get a broad overview of the areas that are strongly impacted by the stratospheric $\mathrm{O}_{3}$ intrusions or/and LRT of pollution.

The bottom-up $\mathrm{NO}_{x}$ emissions from the HTAP2 inventory were assessed on a monthly base by comparing the GEOSChem nitrogen dioxide $\left(\mathrm{NO}_{2}\right)$ columns with the de-striped KNMI (Royal Netherlands Meteorological Institute) OMI column $\mathrm{NO}_{2}$ product version 2.0 (Boersma et al., 2011a, b). For this model evaluation against the OMI L2 products, the $\mathrm{NO}_{2}$ fields calculated by the GEOS-Chem adjoint model were saved daily at 13:30 local solar time, roughly coinciding with the Aura and Aqua overpassing times. Other parameters used in the model column calculations came from the GEOS-5/GEOS-Chem monthly mean conditions. The OMI data that passed the tropospheric quality flag at 13:00-14:00 local time were selected based on the following screening criteria: surface albedo $<0.3$, cloud fraction $<0.2$, solar zenith angle $<75^{\circ}$, and viewing zenith angle $<45^{\circ}$. The averaging kernels (Eskes and Boersma, 2003) and air mass factors in the KNMI product were used to calculate the modeled tropospheric $\mathrm{NO}_{2}$ vertical columns comparable to the OMI. Details of the method to compare the model-based $\mathrm{NO}_{2}$ columns with the KNMI-OMI can be found in Huang et al. (2014).

\section{Results and discussions}

\subsection{Evaluation of the HTAP2 bottom-up $\mathrm{NO}_{x}$ emissions and the model base simulations}

\subsubsection{Evaluation of the bottom-up $\mathrm{NO}_{x}$ emissions}

The comparison of the GEOS-Chem adjoint $\mathrm{NO}_{2}$ columns with the OMI product was used to help assess the bottom-up HTAP2 $\mathrm{NO}_{x}$ emissions. Figure 4 shows that $\mathrm{NO}_{2}$ columns from GEOS-Chem's base simulations over the US are overall overestimated. While grid-scale differences in $\mathrm{NO}_{2}$ columns may not be directly indicative of emissions biases (Qu et al., 
Table 3. (a) Evaluation of the hourly STEM-simulated total $\mathrm{O}_{3}$ (averaged from the three base simulations that used the different free-running boundary conditions) against the CASTNET surface observations for $8 \mathrm{May}-30$ June 2010 . The subregional-mean $R\left(\mathrm{O}_{3}\right.$, EAS, $\left.20 \%\right)$ and its correlation coefficient with the observed $\mathrm{O}_{3}$ are also shown. (b) Evaluation of the hourly STEM-simulated total $\mathrm{O}_{3}$ (separately for three base simulations that used the different free-running boundary conditions) against the CASTNET surface observations for 8 May-30 June 2010.

\begin{tabular}{lrrrrrrrr}
\hline (a) Subregion & $\begin{array}{r}\text { US EPA } \\
\text { regions } \\
\text { contained }\end{array}$ & $\begin{array}{r}\text { Number of } \\
\text { sites }\end{array}$ & $\begin{array}{r}\text { Mean elevation } \\
(\mathrm{km}) \text { : actual/ } \\
\text { model }\end{array}$ & $\begin{array}{r}\text { Mean bias } \\
(\mathrm{ppbv})\end{array}$ & $\begin{array}{r}\text { RMSE } \\
(\mathrm{ppbv})\end{array}$ & $\begin{array}{r}\text { Correlation } \\
\text { (model base; } \\
\text { obs) }\end{array}$ & $\begin{array}{r}\text { Correlation } \\
\text { (obs; modeled } \\
\text { EAS) }\end{array}$ & $\begin{array}{r}\text { Mean EAS } \\
\text { sensitivity } \\
(\mathrm{ppbv})\end{array}$ \\
\hline Western US & $8,9,10$ & 22 & $1.75 / 1.71$ & 1.60 & 4.86 & 0.76 & 0.34 \\
Southern US & 4,6 & 22 & $0.38 / 0.31$ & 20.33 & 22.13 & 0.58 & 0.48 \\
Midwest & 5,7 & 16 & $0.29 / 0.28$ & 15.64 & 17.97 & 0.70 & 0.27 \\
Northeast & $1,2,3$ & 20 & $0.36 / 0.26$ & 20.94 & 24.16 & 0.47 & 0.15 \\
All & $1-10$ & 80 & $0.73 / 0.68$ & 16.17 & 18.30 & 0.66 & 0.17 \\
\hline
\end{tabular}

\begin{tabular}{lrrrrr}
\hline (b) Subregion & $\begin{array}{r}\text { US EPA regions } \\
\text { contained }\end{array}$ & $\begin{array}{r}\text { Number of } \\
\text { sites }\end{array}$ & \multicolumn{2}{c}{$\begin{array}{c}\text { Mean bias (ppbv)/RMSE (ppbv)/ } \\
\text { correlation (model base; obs) }\end{array}$} \\
\cline { 4 - 6 } & & & SNU-GEOS-Chem & C-IFS & RAQMS \\
\hline Western US & $8,9,10$ & 22 & $1.68 / 4.83 / 0.77$ & $4.16 / 6.63 / 0.70$ & $-1.03 / 4.81 / 0.76$ \\
Southern US & 4,6 & 22 & $21.18 / 22.94 / 0.57$ & $20.34 / 22.07 / 0.60$ & $19.48 / 21.45 / 0.56$ \\
Midwest & 5,7 & 16 & $15.77 / 18.17 / 0.70$ & $16.41 / 18.46 / 0.72$ & $14.73 / 17.35 / 0.69$ \\
Northeast & $1,2,3$ & 20 & $21.25 / 24.36 / 0.47$ & $21.86 / 24.80 / 0.48$ & $19.71 / 23.40 / 0.45$ \\
All & $1-10$ & 80 & $16.57 / 18.62 / 0.66$ & $16.89 / 18.84 / 0.67$ & $15.03 / 17.52 / 0.64$ \\
\hline
\end{tabular}

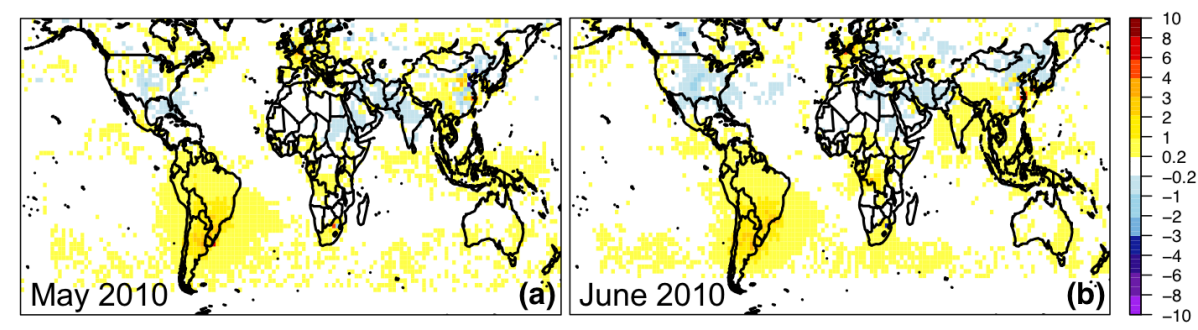

Figure 4. Evaluation of the GEOS-Chem adjoint base $\mathrm{NO}_{2}$ product (recorded at near the satellite overpassing time) with the $\mathrm{OMI} \mathrm{NO}_{2}$ columns. The differences between OMI and GEOS-Chem (OMI-modeled) tropospheric $\mathrm{NO}_{2}$ columns $\left(\times 10^{15}\right.$ molec. $\left.\mathrm{cm}^{-2}\right)$ are shown for (a) May and (b) June 2010. Details of the comparison are included in Sect. 2.3.2.

2017), these discrepancies are possibly due to a positive bias in the bottom-up emissions, mainly from the anthropogenic sources, which have also been pointed out by Anderson et al. (2014) and Travis et al. (2016). A larger OMI-model disagreement was found over the central and eastern US in June 2010 than in May, likely also due to the uncertainty in GEOSChem's soil or lightning $\mathrm{NO}_{x}$ emissions, which appear to be high over these regions (Fig. S1). The $\mathrm{NO}_{2}$ columns in the GEOS-Chem base simulation were overestimated in many northern China rural areas and underpredicted in a few urban areas in East Asia as well as a broad area in southwestern China. The mismatches between model and $\mathrm{OMI} \mathrm{NO}_{2}$ fell within the ranges of the comparison between the GOME2 $\mathrm{NO}_{2}$ column product and six models' simulations over China in summer 2008 (Quennehen et al., 2016). Additionally, the use of monthly mean anthropogenic emissions as well as the overall rough treatment of emission height and temporal profiles can be sources of uncertainty. These global model evaluation results suggest that the EAS-NAM SR relationships analyzed using this inventory may overall overestimate the NAM local contribution and underestimate the EAS contribution. Under different chemical regimes, this statement would also rely on the quality of other $\mathrm{O}_{3}$ precursors' emissions in the HTAP2 inventory, and they may be associated with variable uncertainties depending on the species or emission sector as introduced in Sect. 2.1. Therefore, careful assessment of other key $\mathrm{O}_{3}$ precursors' emissions in the inventory is needed in the future work. It is important to note that uncertainty in satellite retrievals can prevent us from producing an accurate assessment on emissions (e.g., van Noije et al., 2006), and this comparison does not account for the biases in the used OMI data and would be further validated by using other $\mathrm{OMI} \mathrm{NO}$ products as well as the bias-corrected (if applicable) in situ $\mathrm{NO}_{2}$ measurements. We also recommend for more global models to save their calculations more frequently, at least near the satellite overpassing times, for 
a more comprehensive assessment of the emission inventory and a better understanding of the model biases.

\subsubsection{Evaluation of the global model $\mathrm{O}_{3}$ performance in NAM and EAS}

The monthly mean surface $\mathrm{O}_{3}$ from multiple global models' free runs was evaluated with the CASTNET observations at the stations with $95 \%$ of the hourly $\mathrm{O}_{3}$ observation completeness for the 1 May-30 June 2010 period. The mean biases and RMSEs for these 2 months were summarized in Table 2a by US subregions. The three boundary condition model as well as the eight-model ensembles overall underpredicted $\mathrm{O}_{3}$ in the western US (by $\sim 3-6 \mathrm{ppbv}$ ), similar to the HTAP1 model performance over these regions for May-June 2001 presented in Fiore et al. (2009). This can be due to the underestimated trans-boundary pollution (as indicated by the evaluation of modeled $\mathrm{O}_{3}$ profiles with ozonesondes and satellite $\mathrm{O}_{3}$ products). In addition, the coarser model resolutions are less capable of resolving the local features that influence the pollutants' import processes, chemical transformation, and regional processes such as the cross-state pollution transport over complex terrains. The global RAQMS base simulation with satellite assimilation improved the free tropospheric $\mathrm{O}_{3}$ structure as its comparisons with the ozonesondes shows, which also enhanced the simulated monthly mean surface $\mathrm{O}_{3}$ by up to $>10 \mathrm{ppbv}$ in the western US and some coastal areas in the southeastern US (Fig. S2, left). The global models overall significantly overestimated $\mathrm{O}_{3}$ in the other three subregions (by 8-12 ppbv), close to HTAP1 model performance for MayJune 2001 over the similar areas (Fiore et al., 2009) and in the Lapina et al. (2014) study for 2010, in large part due to the uncertainties in the bottom-up emissions as discussed in Sect. 3.1.1. Satellite assimilation led to 2-6 ppbv higher RAQMS surface $\mathrm{O}_{3}$ in the central, southern, and eastern US than in its free simulation, which is associated with higher positive biases.

The surface $\mathrm{O}_{3}$ performance by individual global models varies significantly, for example, with the RMSEs at all CASTNET sites ranging from $\sim 9$ to $>15$ ppbv (Table $2 b$ ). As reported in the literature (e.g., Geddes et al., 2016; Travis et al., 2016), the representation of land use/land cover, boundary layer mixing, and chemistry can be sources of uncertainty for a certain global model (i.e., GEOS-Chem), but how serious these issues were in the other models needs to be investigated further. Some other possible reasons include the variation of these models' non-anthropogenic emission inputs and chemical mechanisms (Table 1c). Future work should emphasize on evaluating and comparing all models on process level to better understand their performance. Except in the northeastern US, the eight-model ensembles show better agreement with the CASTNET $\mathrm{O}_{3}$ observations than the three boundary condition-model ensemble. Overall the threemodel ensemble only outperforms one model but the eight- model ensemble outperforms seven individuals. This reflects that averaging the results from a larger number of models in this case more effectively canceled out the positive or negative biases from the individual models.

The monthly mean surface $\mathrm{O}_{3}$ from multiple global models' free runs was also evaluated with the EANET observations. Among the three boundary condition models, GEOSChem produced higher $\mathrm{O}_{3}$ than the other two throughout the year, and C-IFS $\mathrm{O}_{3}$ is the lowest from April to December. The three-model and eight-model ensembles are lower than the surface $\mathrm{O}_{3}$ observations by $<10$ ppbv during high $\mathrm{O}_{3}$ seasons (winter/spring) but show substantial ( $>10 \mathrm{ppbv}$ ) positive biases during low $\mathrm{O}_{3}$ seasons especially in July and August (Fig. 3b), similar to the HTAP1 model performance over Japan in 2001 (Fiore et al., 2009). During May-June 2010, generally the models performed better at the Japanese sites than at the South Korean sites (Table 2c), with significant positive biases occurring at low $\mathrm{O}_{3}$ regions (e.g., in central Japan) and negative biases found at high $\mathrm{O}_{3}$ regions, mainly owing to the uncertainty in the local and upwind emissions. The different approaches to generate the monthly mean modeled and the observed $\mathrm{O}_{3}$ data may have also contributed to these model-observation discrepancies. Overall $\mathrm{O}_{3}$ performance by individual models varies less significantly than at the CASTNET sites, with RMSEs ranging from 8.6 to $\sim 13 \mathrm{ppbv}$ (Table $2 \mathrm{~b}$ ). The three-model ensemble outperforms two individual models, and the eightmodel ensemble outperforms six individual models. Unlike at the CASTNET sites, the three-model ensemble agrees better with the observations than the eight-model ensemble (Table 2c).

\subsubsection{Evaluation of the STEM regional base simulations with three sets of boundary conditions}

The three STEM base simulations using different boundary conditions were evaluated with the hourly $\mathrm{O}_{3}$ observations at the CASTNET sites in the four US subregions. The evaluation included the 8 May-30 June 2010 period to exclude the results during the 1-week spin-up period. The time series plots of observed and modeled $\mathrm{O}_{3}$ at the western US CASTNET sites show that STEM was capable of capturing several high $\mathrm{O}_{3}$ periods, and it produced larger biases during the nighttime (Fig. 2c), as a result of the poorer WRF performance. Figure $2 \mathrm{c}$ and the evaluation statistics in Table $3 \mathrm{a}-\mathrm{b}$ indicate that STEM/C-IFS $\mathrm{O}_{3}$ concentrations are associated with the highest positive bias and RMSE, while the STEM/GEOS-Chem and STEM/RAQMS predictions were positively and negatively biased by less than $2 \mathrm{ppbv}$, respectively, with similar RMSEs and correlations with the observations. The quality of the three STEM simulation means is closest to the STEM/GEOS-Chem run, with the mean bias/RMSE of $\sim 1.6 / 4.9 \mathrm{ppbv}$, which is much better than the three-boundary model ensemble ( $-5.7 / 10.4 \mathrm{ppbv})$. However, 
this good performance can be a net effect of incorrect partitioning between the trans-boundary and local source contributions, with the former being underestimated and offsetting the overestimation of the latter. Switching the STEM chemical boundary conditions to the assimilated RAQMS base simulation led to increases in the simulated surface $\mathrm{O}_{3}$ concentrations by $>9 \mathrm{ppbv}$ in the western US (Fig. S2, right), associated with higher positive biases (due to several factors discussed in the next paragraph). Regional-scale assimilation could further reduce uncertainties introduced from regional meteorological and emission inputs to obtain better modeled total $\mathrm{O}_{3}$ and the partitioning of trans-boundary versus US contributions (e.g., Huang et al., 2015).

The three STEM base simulations all significantly overpredicted $\mathrm{O}_{3}$ over the rest of the US in part due to the uncertainties in $\mathrm{NO}_{x}$ emissions, with STEM/RAQMS associated with the lowest RMSEs and mean biases, but STEM/CIFS correlated best with the observations (Table 3b). These positive biases are higher than the global model ensembles', which can partially result from the possible unrealistic VOC speciation of the emission inventory and the SAPRC 99 chemical mechanism. Although SAPRC mechanisms have been used in air quality modeling for regulatory applications in some US states such as California, they usually produced higher $\mathrm{O}_{3}$ than other mechanisms such as the CB04 and the CB05 (which were used by some HTAP2 global models, see Table 1c) over the US, and the comparisons between SAPRC 99 and SAPRC 2007 are still in progress (e.g., Luecken et al., 2008; Zhang et al., 2012; Cai et al., 2011). It is important to timely update the chemical mechanisms in the chemistry models, and we also suggest the timely upgrade of the VOC speciation in the bottom-up emission inventories in the US to benefit the air quality modeling. Additionally, the uncertainty from non-anthropogenic emissions, such as the biogenic VOC emissions from WRF/MEGAN, which is known to often have positive biases, can be another cause. As Hogrefe et al. (2011) presented, the MEGAN emissions resulted in a higher $\mathrm{O}_{3}$ response to hypothetical anthropogenic $\mathrm{NO}_{x}$ emission reductions compared with another set of biogenic emission input. Huang et al. (2017) showed that MEGAN's positive biases are in part due to the positively biased temperature and radiation in WRF, and reducing $\sim 2{ }^{\circ} \mathrm{C}$ in WRF's temperature biases using a different land initialization approach led to $\sim 20 \%$ decreases in MEGAN's isoprene emission estimates in September 2013 over some southeastern US regions. These temperature and radiation biases, can also be important sources of uncertainty in the modeled $\mathrm{O}_{3}$ production. Quantifying the impacts of overestimated biogenic emissions and the biased weather fields that contributed to the biases in emissions on the modeled $\mathrm{O}_{3}$ is still an ongoing work. Some existing studies also reported $\mathrm{O}_{3}$ and $\mathrm{NO}_{2}$ biases from other regional models in the eastern US, due to the chemical mechanism and biases in $\mathrm{NO}_{x}$ and biogenic VOC emissions (e.g., Canty et al., 2015). We anticipate that the results from the Air Quality Model Evaluation
International Initiative experiment (e.g., Schere et al., 2012; Solazzo et al., 2012; Galmarini et al., 2015, 2017), which involves more regional model simulations over the US with the similar set of boundary conditions but different chemical mechanisms and non-anthropogenic emission inputs, can help better understand the causes of errors in the simulated total $\mathrm{O}_{3}$.

\subsection{The $\mathrm{NAM}$ surface $\mathrm{O}_{3}$ sensitivity to extra-regional anthropogenic pollutants}

\subsubsection{Global model ensembles}

The impact of all foreign (i.e., non-NAM) anthropogenic sources on NAM surface $\mathrm{O}_{3}$ was first explored, including the spatial distributions of the RERER metric (Eq. 2) based on various global models' simulations (Fig. 5) and the domainwide mean sensitivities $R\left(\mathrm{O}_{3}\right.$, non-NAM, 20\%) (Eq. 1d; Fig. 6). Across NAM, the strongest impacts were found in spring time (March-April-May, larger than $1.5 \mathrm{ppbv}$ in average over the domain), and the weakest impacts are shown during the summertime (June-July-August, 1.0-1.3 ppbv), consistent with the existing knowledge on the seasonal variability of the non-local pollution impacts on NAM for other years (e.g., Fiore et al., 2009; Reidmiller et al., 2009). All global models indicate strong non-NAM anthropogenic source impacts on the western US mainly due to the impact of its high elevation, and also near the US-Mexico border areas, especially southern Texas, due to their vicinity to the Mexican (not included in the NAM source regions, see Fig. 1) emission sources. Over the western states, stronger non-local impacts were reflected from the results based on higher-horizontal-resolution global models (e.g., the $>0.6$ RERER values from the half degree EMEP model, corresponding to its higher $R\left(\mathrm{O}_{3}\right.$, non-NAM, $\left.20 \%\right)$ values than the other models'), similar to the findings in previous modeling studies (Lin et al., 2010, 2012a). Although on a coarse horizontal resolution of $2.8^{\circ}$, OsloCTM3 suggests stronger extra-regional source influences on the northwestern US and the US-Canada border regions than the other models. Its largest number of vertical layers among all global models might be a cause. Larger-than-1 RERER values are often seen near the urban areas and large point sources due to the titration, especially evident from the higher-resolution model results. The $R\left(\mathrm{O}_{3}, \mathrm{EAS}, 20 \%\right)$ values are larger than $1 / 3$ of the $R\left(\mathrm{O}_{3}\right.$, non-NAM, $\left.20 \%\right), 0.2-0.5 \mathrm{ppbv}$ from April to June, more than 3-4 times higher than $R\left(\mathrm{O}_{3}, \mathrm{EUR}, 20 \%\right)$ and $R\left(\mathrm{O}_{3}, \mathrm{SAS}, 20 \%\right)$. Note that all eight models contributed to the $R\left(\mathrm{O}_{3}, \mathrm{EAS}, 20 \%\right)$ calculations, but one or two models did not provide all necessary sensitivity runs to compute RERER, $R\left(\mathrm{O}_{3}\right.$, non-NAM, $\left.20 \%\right), R\left(\mathrm{O}_{3}, \mathrm{EUR}, 20 \%\right)$, or $R\left(\mathrm{O}_{3}, \mathrm{SAS}, 20 \%\right)$.

Comparing to the HTAP1 modeling results, the magnitudes of $R\left(\mathrm{O}_{3}, \mathrm{EUR}, 20 \%\right)$ from this study are smaller by a factor of 2-3; in contrast, the $R\left(\mathrm{O}_{3}\right.$, non-NAM, $\left.20 \%\right)$ and 
Table 4. The ranges and standard deviations (ppbv, separated by “;”) of $R\left(\mathrm{O}_{3}\right.$, [source region], $\left.20 \%\right)$ by 6-8 global models (defined in Eqs. 1a-1d), summarized by months in 2010. The monthly multi-model mean values are shown in Figs. 6-7.

\begin{tabular}{lrrrr}
\hline $\begin{array}{l}\text { Month/source } \\
\text { region }\end{array}$ & $\begin{array}{r}\text { All Foreign/ } \\
\text { non-NAM (ppbv) }\end{array}$ & EUR (ppbv) & EAS (ppbv) & SAS (ppbv) \\
\hline January & $0.38-1.69 ; 0.41$ & $0.002-0.12 ; 0.05$ & $0.02-0.72 ; 0.24$ & $0.001-0.11 ; 0.04$ \\
February & $0.92-2.07 ; 0.37$ & $0.02-0.15 ; 0.05$ & $0.16-0.91 ; 0.28$ & $0.02-0.12 ; 0.04$ \\
March & $1.30-2.37 ; 0.38$ & $0.07-0.21 ; 0.06$ & $0.24-1.03 ; 0.30$ & $0.03-0.12 ; 0.03$ \\
April & $1.42-2.46 ; 0.33$ & $0.09-0.23 ; 0.05$ & $0.33-1.07 ; 0.28$ & $0.04-0.12 ; 0.03$ \\
May & $1.24-1.91 ; 0.21$ & $0.06-0.17 ; 0.04$ & $0.24-0.75 ; 0.19$ & $0.05-0.11 ; 0.02$ \\
June & $1.03-1.41 ; 0.13$ & $0.03-0.07 ; 0.02$ & $0.14-0.39 ; 0.09$ & $0.04-0.07 ; 0.01$ \\
July & $0.86-1.18 ; 0.13$ & $0.02-0.04 ; 0.01$ & $0.08-0.22 ; 0.06$ & $0.01-0.04 ; 0.01$ \\
August & $0.80-1.19 ; 0.13$ & $0.01-0.04 ; 0.01$ & $0.07-0.20 ; 0.05$ & $0.02-0.04 ; 0.01$ \\
September & $0.85-1.18 ; 0.13$ & $0.03-0.05 ; 0.01$ & $0.10-0.25 ; 0.06$ & $0.02-0.06 ; 0.01$ \\
October & $0.96-1.31 ; 0.14$ & $0.04-0.10 ; 0.02$ & $0.17-0.42 ; 0.09$ & $0.03-0.08 ; 0.02$ \\
November & $0.90-1.48 ; 0.19$ & $0.05-0.15 ; 0.04$ & $0.17-0.54 ; 0.14$ & $0.04-0.10 ; 0.02$ \\
December & $0.73-1.67 ; 0.29$ & $0.03-0.18 ; 0.05$ & $0.14-0.66 ; 0.19$ & $0.04-0.12 ; 0.03$ \\
\hline
\end{tabular}

$R\left(\mathrm{O}_{3}\right.$, EAS, $\left.20 \%\right)$ values are $>50 \%$ higher than the HTAP 1 modeling results. The different HTAP1 and HTAP2 results are possibly due to the following three reasons. First, the substantial improvement in the European air quality over the past decades that is shown in Crippa et al. (2016) and Pouliot et al. (2015), which contrasts with the growing anthropogenic emissions from East Asia and other developing countries during 2001-2010. Second, the changes in the HTAP2 experiment setup from HTAP1. This includes the differences in the participating models and the different region definitions, e.g., EUR by HTAP1's definition includes regions in Russia, Belarussia, and Ukraine, the Middle East, and North Africa that are excluded from the HTAP2's EUR domain. For EAS and SAS, however, the regions not overlapped by HTAP1 and HTAP2 are mostly in the less populated/polluted regions. Third, the stronger trans-Pacific transport in 2010 than in 2000-2001, as first introduced in Sect. 2.2.1. Interannual variability of $R\left(\mathrm{O}_{3}\right.$, EAS, $\left.20 \%\right)$ and $R\left(\mathrm{O}_{3}\right.$, non-NAM, $20 \%$ ) is also found between 2010 and 2008-2009, based on the SNU-GEOS-Chem calculations (Fig. S3). Foreign anthropogenic pollution impact on NAM was stronger in 2010 than in 2008-2009, especially in April-May. This can be in part due to the higher $\mathrm{O}_{3}$ precursors' emissions in 2010 from extra-regions including East Asia (Table S1) as well as the spring 2010 meteorological conditions that favored the transPacific pollution transport.

These monthly and regional-mean $R\left(\mathrm{O}_{3}\right.$, EAS, $\left.20 \%\right)$ values suggest that despite dilution along the great transport distance, the EAS anthropogenic sources still had a distinguishable impact on the NAM surface $\mathrm{O}_{3}$. Similar to the findings from the HTAP1 studies, the large intermodel variability (as indicated in Table 4) in the estimates of intercontinental SR relationships indicates the uncertainties of these models in representing the key atmospheric processes which needs more investigations in the future. Figure $6 \mathrm{~b}$ compares the $R\left(\mathrm{O}_{3}, \mathrm{EAS}, 20 \%\right)$ values estimated by individual boundary condition models, their ensemble mean sensitivities, and the eight-global-model mean. The averaged $R\left(\mathrm{O}_{3}\right.$, EAS, 20\%) from the boundary condition model results are smaller than the eight-global-model mean, and, except for July-October 2010, GEOS-Chem gives higher $R\left(\mathrm{O}_{3}\right.$, EAS, $20 \%)$ than RAQMS and C-IFS, consistent with its highest $\mathrm{O}_{3}$ prediction in the EAS source region (Fig. 3b). Overall, $R\left(\mathrm{O}_{3}, \mathrm{EAS}, 20 \%\right)$ and its intermodel differences are much smaller than the biases of the modeled total $\mathrm{O}_{3}$ in NAM. Other factors can contribute more significantly to the biases in the modeled total $\mathrm{O}_{3}$, such as the stratospheric $\mathrm{O}_{3}$ intrusion and the local $\mathrm{O}_{3}$ formation, and assessing the impacts from these factors would be also helpful for understanding the uncertainties in the modeled $\mathrm{O}_{3}$.

The $\mathrm{O}_{3}$ sensitivities in response to the perturbations of individual species or sector emissions in East Asia, estimated by the GEOS-Chem adjoint model, were also analyzed (Fig. S3). These sensitivities show similar seasonal variability to $R\left(\mathrm{O}_{3}\right.$, EAS, $\left.20 \%\right)$, with the values $\sim$ twice as high in the spring than in summer, also consistent with the results on previous years based on the $20 \%$ emission perturbation approach (e.g., Fiore et al., 2009; Brown-Steiner and Hess, 2011; Emmons et al., 2012). However, this seasonal variability is weaker than the results based on the tagged tracer approach for earlier years. Using the CAM-Chem model, Brown-Steiner and Hess (2011) reported that during the springtime, Asian $\mathrm{O}_{3}$ created from the anthropogenic and biofuel $\mathrm{NO}_{x}$ emissions affected $\mathrm{NAM} \mathrm{O}_{3} \sim$ three times as strongly as in summer. This is because the nonlinear $\mathrm{O}_{3}$ chemistry, which is stronger outside of summer, caused larger $\mathrm{O}_{3}$ responses to a $100 \%$ reduction of $\mathrm{NO}_{x}$ emissions than 5 times of the $\mathrm{O}_{3}$ responses to a $20 \%$ reduction of $\mathrm{NO}_{x}$ emissions. The EAS anthropogenic $\mathrm{NO}_{x}$ emissions more strongly impacted the NAM surface $\mathrm{O}_{3}$ than the other major $\mathrm{O}_{3}$ precursors, similar to the findings in Fiore et al. (2009) and Reidmiller et al. (2009) using the perturbation approach, 


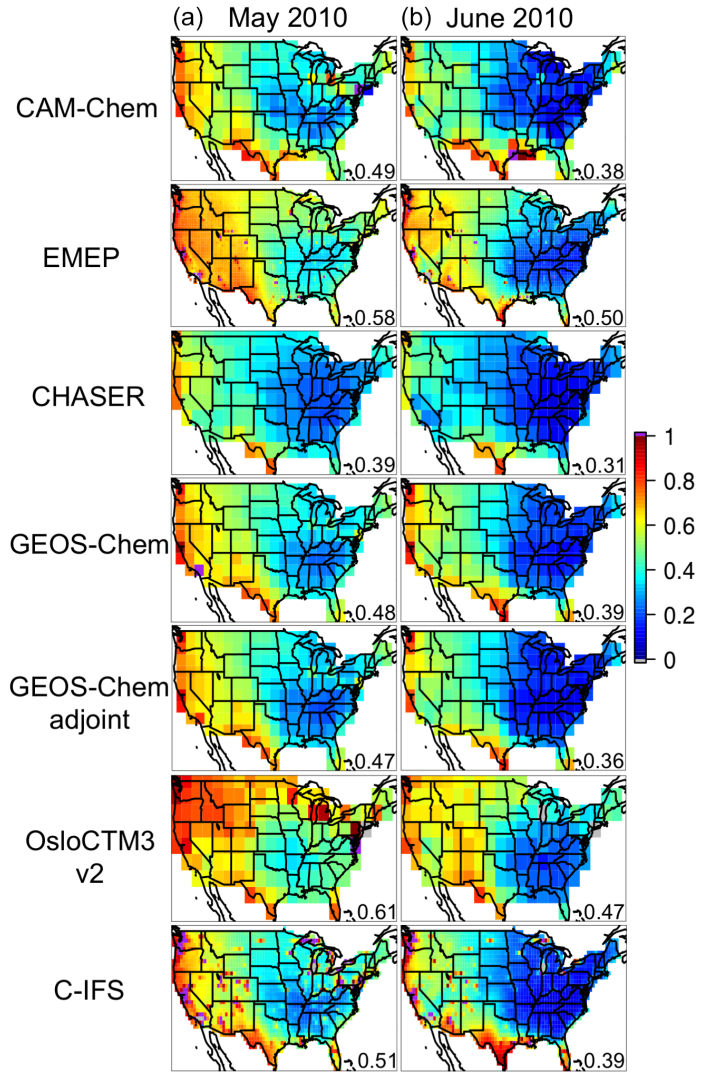

Figure 5. The RERER maps in (a) May and (b) June 2010 over the continental US, calculated based on the monthly mean $\mathrm{O}_{3}$ from multiple global models' base and emission sensitivity simulations. The RERER metric (unitless) was defined in Eq. (2) in the text. Values larger than 1 and smaller than 0 are shown in purple and gray, respectively. The US (including continental US as well as Hawaii, which is not shown in the plots) mean values are indicated for each panel at the lower right corner. All models show declining RERER values from May to June, and the seven-model mean RERER values for May and June 2010 are $\sim 0.5$ and $\sim 0.4$, respectively.

as well as the conclusions in Lapina et al. (2014) based on the adjoint sensitivity analyses. Emissions from the power and industrial sectors are higher in East Asia than in the other sectors (Table S1), resulting in its stronger influences on the NAM surface $\mathrm{O}_{3}$. As the observed $\mathrm{NO}_{2}$ columns started to drop since 2010 due to the effective denitration devices implemented at the Chinese power and industrial plants (e.g., Liu et al., 2016), depending on the changes in the VOC emissions, different $R\left(\mathrm{O}_{3}, \mathrm{EAS}, 20 \%\right)$ values for the years after 2010 are anticipated. Therefore, continued studies to assess the East Asian anthropogenic pollution impacts on NAM during more recent years is needed. As emissions from various source sectors can differ by their emitted altitudes and temporal (from diurnal to seasonal) profiles, an effort should also be made to have the models timely update the heights and temporal profiles of the emissions from those various sectors.

\subsubsection{Regional model sensitivities and their connections with the boundary condition models' sensitivities}

The monthly mean STEM surface $R\left(\mathrm{O}_{3}\right.$, EAS, $\left.20 \%\right)$ sensitivities based on different boundary condition models were intercompared and also compared with the $R\left(\mathrm{O}_{3}\right.$, EAS, $20 \%$ ) values estimated by their boundary condition models as well as the global model ensemble mean (Fig. 7). For both May and June 2010, the domain-wide mean $R\left(\mathrm{O}_{3}\right.$, EAS, $20 \%$ ) values from STEM/RAQMS were higher than the estimates from RAQMS by $0.03 \mathrm{ppbv}$; the STEM/GEOS-Chem $R\left(\mathrm{O}_{3}\right.$, EAS, $\left.20 \%\right)$ values are lower than those of GEOSChem by $0.01-0.06 \mathrm{ppbv}$, and the STEM/C-IFS $R\left(\mathrm{O}_{3}\right.$, EAS, $20 \%$ ) is 0.02 ppbv higher than C-IFS's in June but slightly $(\ll 0.01 \mathrm{ppbv})$ lower in May. These differences are overall smaller than the inter-global model differences, and can be due to various factors including the uncertainties in boundary condition chemical species mapping, and the different meteorological, terrain fields, and chemistry in the global and regional model pairs. The STEM $R\left(\mathrm{O}_{3}\right.$, EAS, $\left.20 \%\right)$ ensemble mean values, however, are less than $0.02 \mathrm{ppbv}$ different from its boundary condition model's ensemble mean for both months. The STEM $R\left(\mathrm{O}_{3}\right.$, EAS, $\left.20 \%\right)$ ensemble mean value in June is also close to the eight-global-model-ensemble mean but is $\sim 0.05$ ppbv lower than the eight-model mean in May. Choosing other/more global model outputs as STEM's boundary conditions may lead to different STEM ensemble mean $R\left(\mathrm{O}_{3}\right.$, EAS, $\left.20 \%\right)$ estimates. We also found that the period-mean $R\left(\mathrm{O}_{3}\right.$, EAS, $\left.20 \%\right)$ values of $\sim 0.2 \mathrm{ppbv}$ sampled only at the CASTNET sites (Table $3 a$ ) are smaller than those averaged in all model grids. This indicates that currently the sparsely distributed surface network (especially over the western US, which is more strongly affected by the extra-regional sources than the other US regions) may miss many LRT episodes that impact NAM. The planned geostationary satellites with $\sim 2-5 \mathrm{~km}$ footprint sizes and hourly sampling frequency (Hilsenrath and Chance, 2013; Zoogman et al., 2017) will help better capture the high $\mathrm{O}_{3}$ and LRT episodes in these regions.

The spatial patterns of the monthly mean STEM surface $R\left(\mathrm{O}_{3}\right.$, EAS, $\left.20 \%\right)$ sensitivities based on the three boundary condition models are notably different but overall resemble what is estimated by the corresponding boundary condition model, and the STEM sensitivities show more local details in certain high-elevation regions in the US west (Fig. 8 shows the June 2010 conditions as an example). These different sensitivities were investigated further by examining the $R\left(\mathrm{O}_{3}\right.$, EAS, $20 \%$ ) values near the source regions (i.e., East Asia) as well as near the receptor regions (Fig. 9). More East Asian anthropogenic $\mathrm{O}_{3}$ seems to be transported at the upper troposphere in RAQMS than in the other two models. GEOSChem and RAQMS $R\left(\mathrm{O}_{3}\right.$, EAS, $\left.20 \%\right)$ sensitivities are similar over EAS as well as the 500-900 $\mathrm{hPa}$ near the receptor in the eastern Pacific (at $\sim 135^{\circ} \mathrm{W}$ ), which are the altitudes US surface $\mathrm{O}_{3}$ are most strongly sensitive to during the summer- 

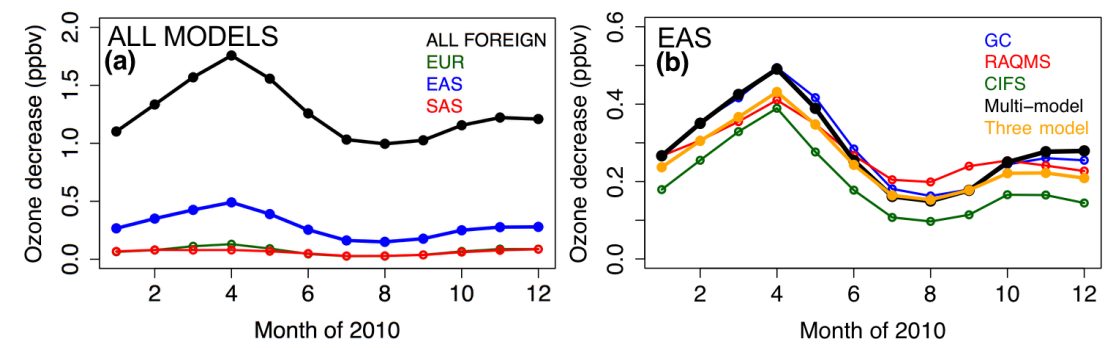

Figure 6. (a) North American (130-65 $\left.\mathrm{W} ; 20-50^{\circ} \mathrm{N}\right)$ mean $\mathrm{O}_{3}$ sensitivity to $20 \%$ anthropogenic emission reductions in various non-North American regions, averaged from multiple (six-eight, see details in text) global models. (b) North American surface $R\left(\mathrm{O}_{3}, \mathrm{EAS}, 20 \%\right)$ values, as estimated by single (the three STEM boundary condition models) or multi-global model means. The "Multi-model" and "Three model" in the legend indicate the mean sensitivities of all eight global models and only of the three boundary condition models, respectively.

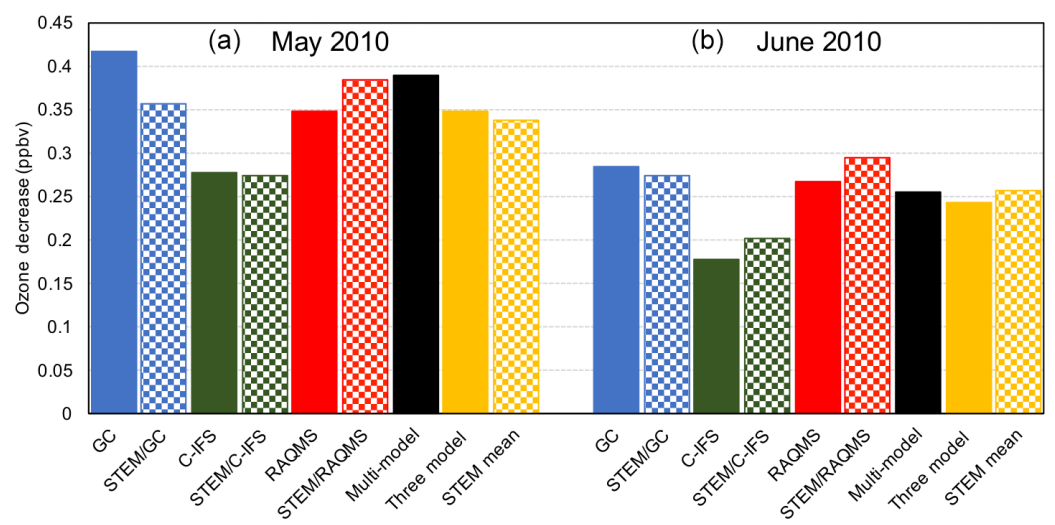

Figure 7. Monthly mean North American $\left(130-65^{\circ} \mathrm{W} ; 20-50^{\circ} \mathrm{N}\right)$ surface $R\left(\mathrm{O}_{3}\right.$, EAS, $\left.20 \%\right)$ values from multiple global and regional model simulations for (a) May and (b) June 2010. STEM model mean values were calculated from its hourly output from 8 May and on. The "Multi-model" and "Three model" in the legend indicate the mean sensitivities of all eight global models and only of the three boundary condition models, respectively.

time as concluded from previous studies (e.g., Huang et al., 2010, 2013a; Parrish et al., 2010). Despite the close NAM domain-wide mean values from the STEM/GEOS-Chem and STEM/RAQMS, the spatial patterns of $R\left(\mathrm{O}_{3}, \mathrm{EAS}, 20 \%\right)$ over NAM differ in these two cases, with the latter case showing sharper gradients especially in the western US, partially due to the impact of its higher horizontal resolution. The $R\left(\mathrm{O}_{3}, \mathrm{EAS}, 20 \%\right)$ values from STEM/C-IFS are lower than from the other two cases both near the sources and at (near) NAM. The STEM surface (also near surface, not shown in figures) $R\left(\mathrm{O}_{3}\right.$, EAS, $\left.20 \%\right)$ does not spatially correlate well with the column $R\left(\mathrm{O}_{3}\right.$, EAS, $\left.20 \%\right)$, the latter of which contributed more to the base case $\mathrm{O}_{3}$ columns, indicating that a good portion of the transported East Asian pollution did not descend to the lower altitudes to impact the boundary layer/ground level air quality. An additional regional simulation was performed in which the STEM boundary conditions were downscaled from a RAQMS simulation without the East Asian anthropogenic emissions. The nonlinear emission perturbation- $\mathrm{O}_{3}$ response relationships, as the larger-than-1 $S_{\mathrm{O}_{3}}$ metric (Eq. 3) indicates, are seen across the domain, for both the surface and column $\mathrm{O}_{3}$ (Fig. 8). $S_{\mathrm{O}_{3}}$ val- ues for column $\mathrm{O}_{3}$, ranging from 1.15-1.25 in most regions, are overall $\sim 0.05$ higher than $S_{\mathrm{O}_{3}}$ for the surface $\mathrm{O}_{3}$. Therefore, the full source contribution obtained by linearly scaling the receptor regional-mean $\mathrm{O}_{3}$ sensitivity to the $20 \%$ reduction in the source region emissions may be underestimated by at least $\sim 10 \%$.

\subsubsection{Regional model MDA8 sensitivities on all days and during the $\mathrm{O}_{3}$ exceedances}

The temporal variability of the STEM $R\left(\mathrm{O}_{3}\right.$, EAS, $\left.20 \%\right)$ ensemble sensitivities were also studied. For most US subregions, 3-6 LRT episodes (defined as when the sensitivities are above the period mean) were identified during May-June. Only in certain regions, we find that the planetary boundary layer heights (PBLHs) were higher during the LRT episodes (i.e., the daily daytime-mean $R\left(\mathrm{O}_{3}\right.$, EAS, $\left.20 \%\right)$ and PBLHs show medium-to-strong positive correlations $(r>0.5))$, as these correlations may have been complicated by the relationships between the PBLHs and the local influences. Throughout this period, the hourly $R\left(\mathrm{O}_{3}\right.$, EAS, $\left.20 \%\right)$ and the observed $\mathrm{O}_{3}$ at the surface CASTNET sites are weakly 


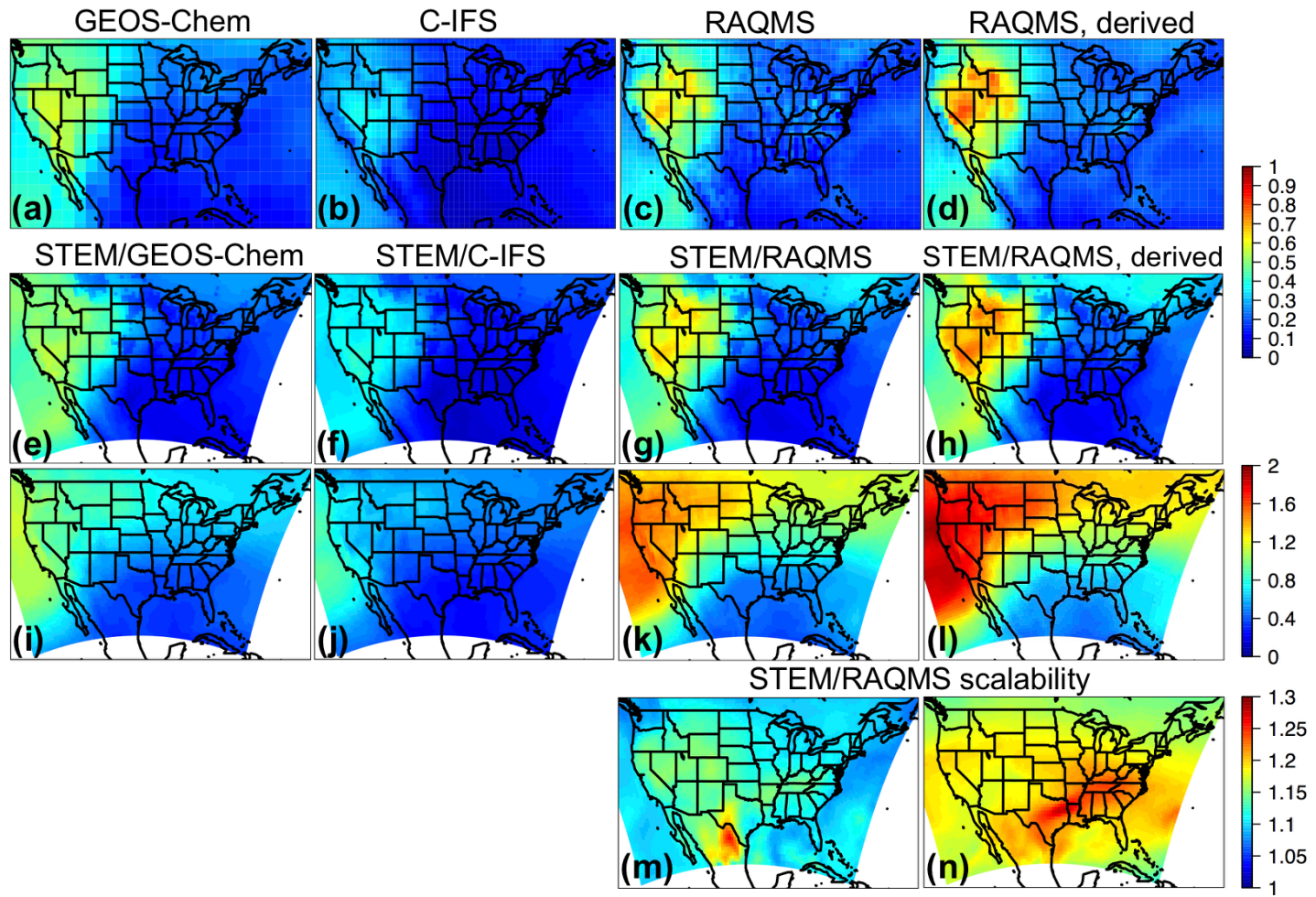

Figure 8. The monthly mean $R\left(\mathrm{O}_{3}\right.$, EAS, $20 \%$ ) in June 2010 for (a-d) surface $\mathrm{O}_{3}$ (ppbv) from the three boundary condition models, (e-h) STEM surface $\mathrm{O}_{3}$ (ppbv), and (i-l) STEM column $\mathrm{O}_{3}\left(\times 10^{16}\right.$ molecules $\left.\mathrm{cm}^{-2}\right)$. $R\left(\mathrm{O}_{3}\right.$, EAS, 20\%) values from the simulations associated with GEOS-Chem, ECMWF C-IFS, and RAQMS are shown in (a, e, i), (b, f, j), and (c, $\mathbf{g}, \mathbf{k})$, respectively. Panels (d, h, l) show $1 / 5$ of the $R\left(\mathrm{O}_{3}\right.$, EAS, $\left.100 \%\right)$ values from the simulations related to RAQMS. STEM/RAQMS-based "scalability" $S_{\mathrm{O}_{3}}$ (Eq. 3) values over $\mathrm{NAM}$ are shown for $(\mathbf{m})$ surface and (n) column $\mathrm{O}_{3}$.
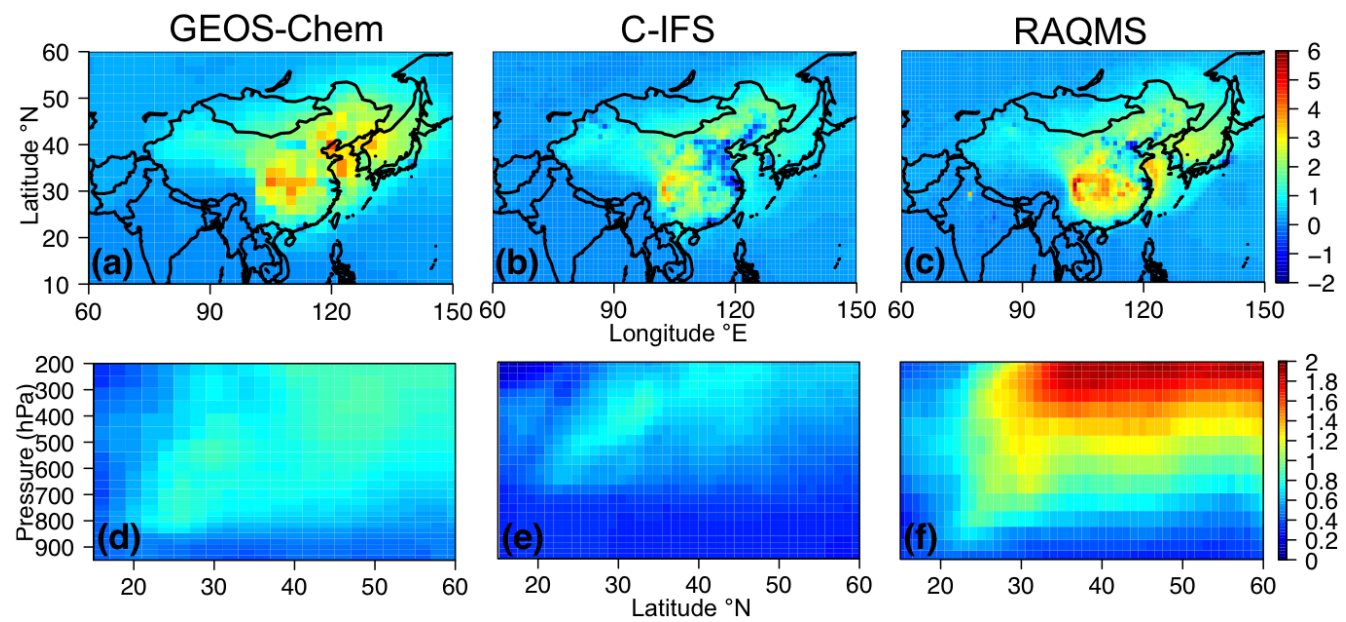

Figure 9. The monthly mean $R\left(\mathrm{O}_{3}\right.$, EAS, $\left.20 \%\right)$ in ppbv in June 2010 from the three boundary condition models at the source and near the receptor regions: (a-c) surface $\mathrm{O}_{3}$ in East Asia; and (d) $\mathrm{O}_{x}$ (GEOS-Chem) or (e-f) $\mathrm{O}_{3}$ (ECMWF C-IFS and RAQMS) along the cross section of $135^{\circ} \mathrm{W}$ (near the west boundary of the STEM model domain as defined in Fig. 2a). 


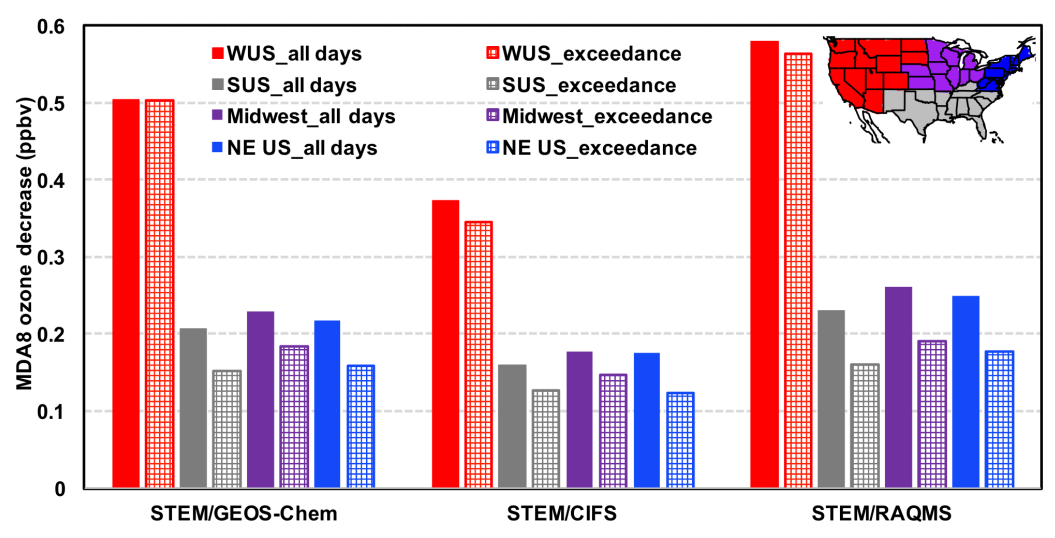

Figure 10. STEM $R$ (MDA8, EAS, 20\%) for May-June 2010 in four US subregions (defined in the inset panel, also consistent with the definitions in Figs. 2 and S4 and Tables 2 and 3), averaged on all days (bars with solid fill) and only on the days when the simulated total MDA8 $\mathrm{O}_{3}$ concentrations were over $70 \mathrm{ppbv}$ (bars with grid pattern fill). The results from the STEM runs using GEOS-Chem, ECMWF C-IFS, and RAQMS boundary conditions are shown separately.

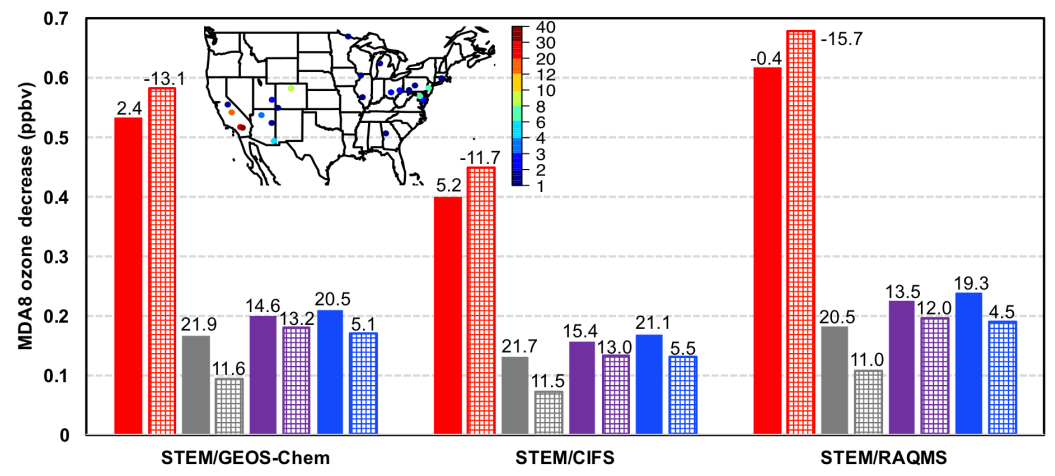

Figure 11. STEM $R$ (MDA8, EAS, $20 \%$ ) for May-June 2010 at the CASTNET sites in four US subregions (same definition as in the Fig. 10 inset), averaged on all days (bars with solid fill) and only on the days when the observed $\mathrm{MDA} 8 \mathrm{O}_{3}$ concentrations were over 70 ppbv (bars with grid pattern fill). The results from the STEM runs using GEOS-Chem, ECMWF C-IFS, and RAQMS boundary conditions are shown separately. Biases for the corresponding model base runs are shown above the bar plots. Inset shows the number of days when the observed MDA8 $\mathrm{O}_{3}$ concentrations were over 70 ppbv at various CASTNET sites.

correlated (Table 3a), but they display similar diurnal cycles (e.g., Fig. 2c and d for the western US sites), possibly because the deeper boundary layer depth during the daytime enhanced entrainment down-mixing of the extra-regional pollutants to the surface. The identified diurnal variability of the $R\left(\mathrm{O}_{3}\right.$, EAS, $\left.20 \%\right)$ values can cause differences in the calculated MDA 8 and all-hour mean $R\left(\mathrm{O}_{3}, \mathrm{EAS}, 20 \%\right)$ values. Figure $\mathrm{S} 4$ shows that the mean $R$ (MDA8, EAS, $20 \%$ ) values, usually at daytime, are higher than the all-hour averaged $R\left(\mathrm{O}_{3}\right.$, EAS, $\left.20 \%\right)$ in most STEM model grids during both months. Therefore, it is important for more HTAP2 participating models to save their outputs hourly in order to conveniently compute the policy-relevant metrics for the $\mathrm{O}_{3}$ sensitivities. Additionally, the hourly sampling frequency of the planned geostationary satellites is anticipated to be more helpful for evaluating the impacts of the LRT episodes.

The STEM $R$ (MDA8, EAS, $20 \%$ ) in all model grids within the four US subregions were averaged on all days during May-June 2010 and only on the days when the simulated total MDA8 $\mathrm{O}_{3}$ is over 70 ppbv (Fig. 10). These sensitivities also show appreciable spatial variability: from $0.35-$ $0.58 \mathrm{ppbv}$ in the western US (also with the largest standard deviations, not shown), which is slightly higher than the HTAP1 results reported by Reidmiller et al. (2009) for Spring 2001, to $\sim 0.1-0.25 \mathrm{ppbv}$ in the remaining three subregions, which is close to the Reidmiller et al. (2009) results.

Comparing the solid bar plots in Figs. 10-11, we found that on all days in the three non-western subregions, $R$ (MDA8, EAS, $20 \%$ ) values sampled at CASTNET sites are slightly smaller than those computed for all model grids, while in the non-western states the opposite differences are seen. This again suggests that expanding observation network would help better capture the high $\mathrm{O}_{3}$ and LRT episodes.

Figure 10 suggests smaller $R$ (MDA8, EAS, $20 \%$ ) values during the high $\mathrm{O}_{3}$ days in all subregions. However, STEM's 


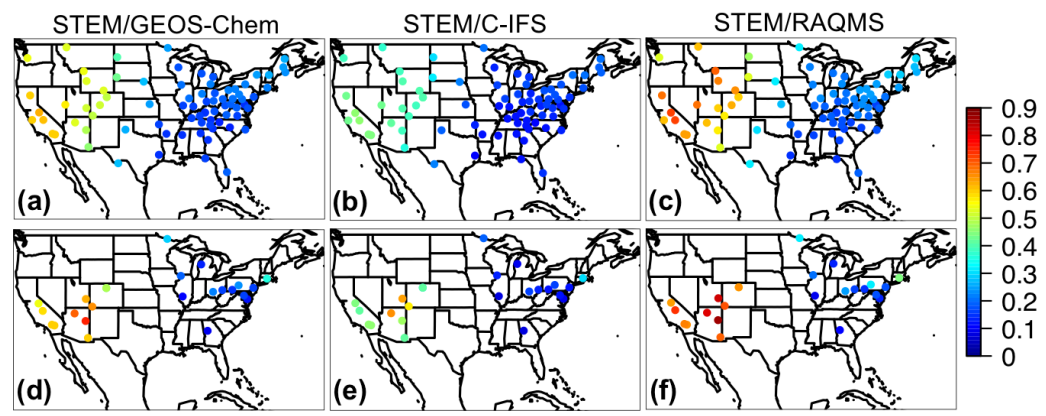

Figure 12. STEM $R($ MDA8, EAS, $20 \%$ ) in ppbv for May-June 2010 at the CASTNET sites on (a-c) all days and (d-f) the days when the observed MDA8 $\mathrm{O}_{3}$ concentrations were over 70 ppbv. The results from the STEM runs using (a, d) GEOS-Chem, (b, e) ECMWF C-IFS, and $(\mathbf{c}, \mathbf{f})$ RAQMS boundary conditions are shown separately.

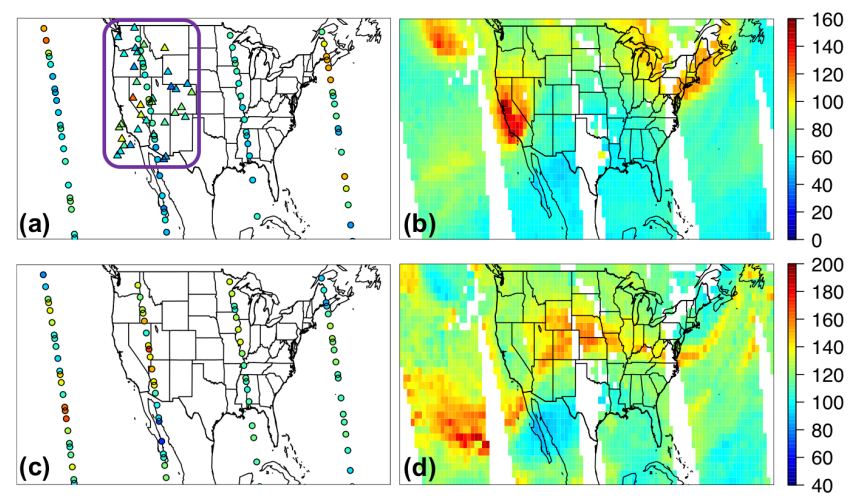

Figure 13. Case study of 9 May 2010: (a-b) Ozone (ppbv) and (c-d) $\mathrm{CO}$ (ppbv) at $\sim 500 \mathrm{hPa}$ from the L2 (a, c) TES retrievals (circles) and (b, d) L3 AIRS products at early afternoon local time. The L2 IASI $\mathrm{O}_{3}$ (ppbv) at $\sim 500 \mathrm{hPa}$ retrieved using the TES algorithm (details in Sect. 2.3.2) at the mid-morning local times is shown on (b) as triangles. The $\mathrm{O}_{3}$ profiles within the purple box in (a) were used in the model evaluation shown in Fig. 14.

total $\mathrm{O}_{3}$ concentrations at CASTNET sites during the $\mathrm{O}_{3}$ exceedances were substantially overpredicted in non-western US regions while significantly underpredicted in the western US (see mean biases above the bar plots in Fig. 11). Therefore, the $R$ (MDA8, EAS, $20 \%$ ) values shown in Fig. 10 during the model-based periods of $\mathrm{O}_{3}$ exceedances can represent the sensitivities during the actual periods of $\mathrm{O}_{3}$ compliance in non-western US regions and may not represent the sensitivities during all actual $\mathrm{O}_{3}$ exceedances in the western US. Figures 11-12 show that if calculated only at the CASTNET sites during the exceedances, in non-western US regions, $R$ (MDA8, EAS, $20 \%$ ) is $0.02-0.07$ ppbv smaller during the high $\mathrm{O}_{3}$ total days. This is qualitatively consistent with the findings in Reidmiller et al. (2009) and is possibly due to the fact that the LRT impacts were stronger on some days with good dispersion conditions when the NAAQS was not exceeded but weaker on some high $\mathrm{O}_{3}$ days under stagnant conditions. In contrast, western US $R$ (MDA8, EAS,
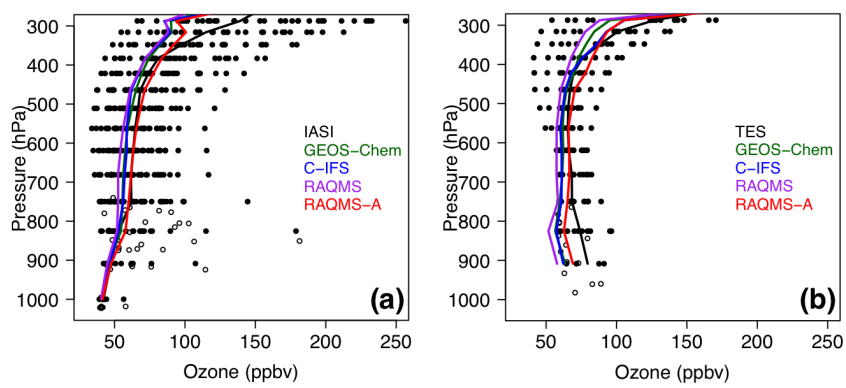

Figure 14. Case study of 9 May 2010: the comparisons between (a) IASI and (b) TES $\mathrm{O}_{3}$ in the western US with the simulated $\mathrm{O}_{3}$ in the STEM runs using the GEOS-Chem (green), C-IFS (blue), RAQMS (purple), and assimilated RAQMS (red) boundary conditions. The $\mathrm{O}_{3}$ profiles within the purple box in Fig. 13a were used in the evaluation. Observation operators were applied in the comparisons (details in Sect. 2.3.2). Solid and open dots are TES or IASI data at the TES retrieval reporting levels and at the variable surface pressure levels, respectively. Solid lines are median $\mathrm{O}_{3}$ profiles from the satellite observations and the different STEM simulations, calculated only on the TES retrieval reporting levels.

$20 \%)$ at CASTNET sites was $\sim 0.05$ ppbv higher on high $\mathrm{O}_{3}$ days than for all days, and these differences are larger in rural/remote areas where local influences are less dominant. As a result, the medium-to-strong positive correlations are found between the modeled LRT of pollution and the total $\mathrm{O}_{3}$ in these regions (Table 3a; Lin et al., 2012a).

\subsection{Case studies of spring ( 9 May) and summer (10 June) LRT events mixed with stratospheric $\mathrm{O}_{3}$ intrusions}

Lin et al. (2012a, b) and Neuman et al. (2012) showed that the trans-Pacific pollution transport intensely impacted the western US during 8-10 May 2010, intermingled with a stratospheric intrusion that contributed to at least $1 / 3$ of the total $\mathrm{O}_{3}$ in some high-elevation regions. This episode is indeed indicated by the $\mathrm{O}_{3}$ and $\mathrm{CO}$ products from AIRS and TES at $\sim 500 \mathrm{hPa}$ over the eastern Pacific (Fig. 13), and the ob- 

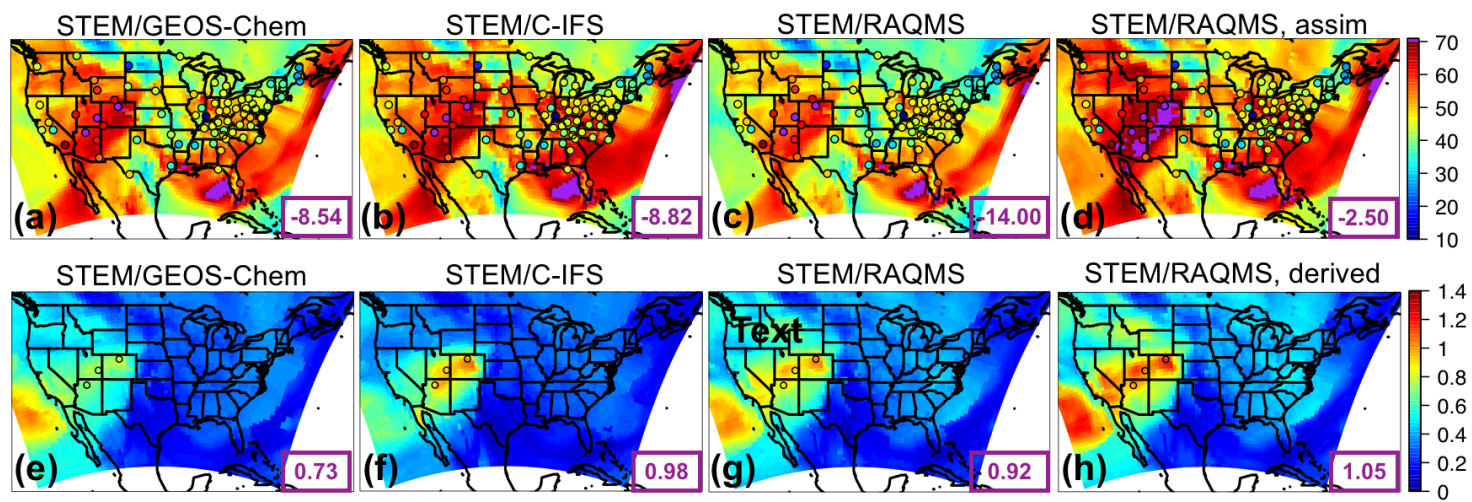

Figure 15. Case study of 9 May 2010: (a-d) Surface MDA8 total $\mathrm{O}_{3}$ and (e-h) surface $R$ (MDA8, EAS, 20\%) from the STEM simulations using the (a, e) GEOS-Chem, $(\mathbf{b}, \mathbf{f})$ ECMWF C-IFS, and $(\mathbf{c}, \mathbf{g})$ RAQMS free run as the boundary conditions. (d) Surface MDA8 total $\mathrm{O}_{3}$ in a STEM base simulation using the RAQMS assimilation run as the boundary conditions. CASTNET observations are overlaid in filled circles in (a-d). (h) is $1 / 5$ of the surface $R$ (MDA8, EAS, $100 \%$ ) from STEM/RAQMS simulations. The conditions at $\sim 400-500 \mathrm{hPa}$ are shown in Fig. S5. Purple numbers at the lower right corners of (a-d) and (e-h) are mean model biases and mean $R($ MDA8, EAS, 20\%) values in ppbv at the three mountain sites (Grand Canyon NP, AZ; Canyonlands NP, UT; and Rocky Mountain NP, CO) where $\mathrm{O}_{3}$ exceedances were observed on this day. The locations of these sites are shown in (e-h) as open circles.

served TES and IASI $\mathrm{O}_{3}$ profiles over the western US indicated elevated $\mathrm{O}_{3}$ levels ( $>80 \mathrm{ppbv}$ ) at $700-900 \mathrm{hPa}$. Huang et al. (2013b) found that the meteorological conditions during this period (i.e., a strong jet at $\sim 700 \mathrm{hPa}$ with wind speed $>20 \mathrm{~m} \mathrm{~s}^{-1}$ shifted southwesterly when passing southern California and continued to travel towards the mountain states), along with the orographic lifting, efficiently exported the southern California anthropogenic pollution, which was chemically coupled with the extra-regional pollution and significantly enhanced the $\mathrm{O}_{3}$ levels in the US intermountain west.

We selected this episode to compare the STEM surface total $\mathrm{O}_{3}$ concentrations as well as the $R\left(\mathrm{O}_{3}\right.$, EAS, $\left.20 \%\right)$ sensitivities based on the different HTAP2 boundary condition models. Figure 14 evaluates the simulated $\mathrm{O}_{3}$ profiles in the western US from several STEM base simulations against the TES and IASI $\mathrm{O}_{3}$ retrievals, and Fig. 15a$\mathrm{d}$ indicate the performance of the daily surface total MDA8 $\mathrm{O}_{3}$ from these simulations. We found that the underestimated free tropospheric $\mathrm{O}_{3}$ from the STEM simulations that used any single free-running chemical boundary conditions contributed to the underestimated STEM surface $\mathrm{O}_{3}$ in the high-elevation mountain states - e.g., by $9-14$ ppbv at three CASTNET sites (Grand Canyon National Park [NP], AZ; Canyonlands NP, UT; and Rocky Mountain NP, CO) where $\mathrm{O}_{3}$ exceedances were observed. The unsatisfactory performance by free-running global models during high $\mathrm{O}_{3}$ events would pose difficulties for regional models (regardless of their resolutions and other configurations, parameterization) to accurately estimate the SR relationships using boundary conditions downscaled from these model runs. The STEM base simulation using the RAQMS assimilated fields as the boundary conditions agrees most with the observed $\mathrm{O}_{3}$ at the CASTNET sites as well as the TES and IASI $\mathrm{O}_{3}$ profiles in the western states. Similar to the conclusions drawn in Huang et al. (2010, 2015) for summer 2008, we again demonstrated the robustness of satellite chemical data assimilation for improving the boundary condition models' $\mathrm{O}_{3}$ performance. As the enhancement of $\mathrm{O}_{3}$ due to the assimilation is much larger than the $\mathrm{O}_{3}$ sensitivities to the EAS anthropogenic emissions, the assimilation mainly improved the contributions from other sources, possibly including the stratospheric $\mathrm{O}_{3}$.

The quality of the model boundary conditions only indicates how well the total "transported background" component is represented and can not be directly connected with the accuracy of the model-estimated $R\left(\mathrm{O}_{3}\right.$, EAS, $\left.20 \%\right)$ sensitivities, which also show notable intermodel differences. The estimated $R$ (MDA8, EAS, $20 \%$ ) in the different STEM cases range from $<1.0$ to $\sim 1.3 \mathrm{ppbv}$, at least $40 \%$ higher than the May-June period mean in Figs. 10-11. The mean $R$ (MDA8, EAS, $20 \%$ ) at three high $\mathrm{O}_{3}$ CASTNET sites ranges from 0.73 (STEM/GEOS-Chem) to $0.98 \mathrm{ppbv}$ (STEM/C-IFS), with the mean $S_{\mathrm{O}_{3}}$ of $\sim 1.14$ at these sites based on the STEM/RAQMS runs due to the nonlinear emission perturbation- $\mathrm{O}_{3}$ response relationships (Fig. 15e-h). $R$ (MDA8, EAS, $100 \%$ ) from the STEM/RAQMS case is as high as $>7 \mathrm{ppbv}$ over the high-terrain regions. These are of smaller magnitudes than the estimates in Lin et al. (2012a), possibly due to the differences in the used models and the bottom-up emission inputs.

A stratospheric $\mathrm{O}_{3}$ intrusion also affected the northeastern US on the same day, as revealed by the satellite midtropospheric $\mathrm{O}_{3}$ and $\mathrm{CO}$ observations (Fig. 13). This intrusion was mixed with LRT East Asian pollution (Figs. 15 and S5). However, this intrusion did not enhance the north- 


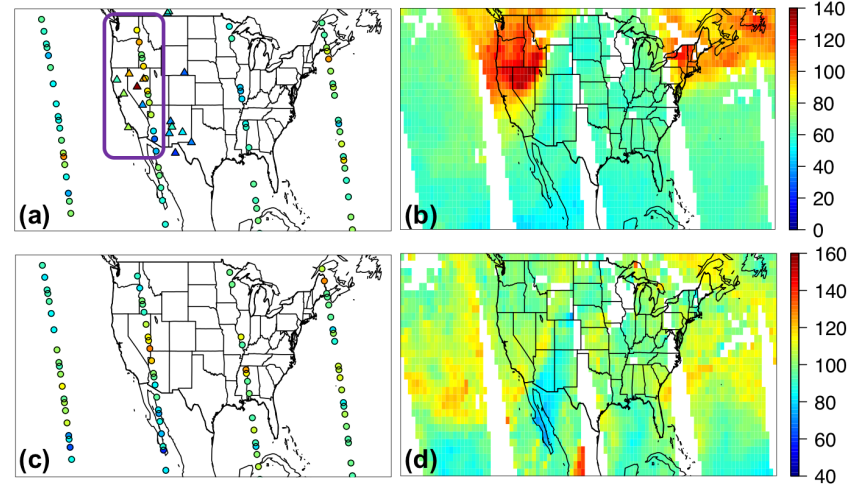

Figure 16. Same as Fig. 13, but for a case study of 10 June 2010.

eastern US boundary layer/surface $\mathrm{O}_{3}$ concentrations, which were actually anomalously low (MDA $8<40 \mathrm{ppbv}$ ), as indicated by the model base simulations and the CASTNET observations (Fig. 15a-d). Similar characteristics during summertime stratospheric $\mathrm{O}_{3}$ intrusion events around this region have been discussed by Ott et al. (2016). The East Asian pollution affected the surface $\mathrm{O}_{3}$ levels less intensely $(<50 \%)$ in these regions than in the US west, due to the greater transport distances, stronger local emission influence on chemical production/loss, shallower PBLHs, and the impact of the overall flat terrain in the US east.

A summertime LRT event on 9-10 June is analyzed to contrast with the 9 May case study. Lin et al. (2012b) showed that $>80 \mathrm{ppbv}$ of ozonesonde data in northern California at 2-6 km measured the stratospheric $\mathrm{O}_{3}$ remnants during this episode, and the transported stratospheric $\mathrm{O}_{3}$ contributed to as much as $\sim 50 \%$ of the total $\mathrm{O}_{3}$ in southern California based on their model calculations. We show that on 10 June over 100 ppbv of $\mathrm{O}_{3}$, as well as $<90$ ppbv $\mathrm{CO}$, was observed by satellites at $\sim 500 \mathrm{hPa}$ above Nevada and northern California (Fig. 16), which again was substantially underestimated by all free-running models (Fig. 17), resulting in the underpredicted total $\mathrm{O}_{3}$ at two CASTNET sites in southern California (Converse Station and Joshua Tree NP) that experienced $\mathrm{O}_{3}$ exceedances on this day (Fig. 18a-c). The negative biases in the transported background $\mathrm{O}_{3}$ and surface MDA8 $\mathrm{O}_{3}$ were successfully reduced by incorporating satellite data (Figs. 17 and 18d).

Figure 18e-h show that LRT of EAS anthropogenic pollution also strongly affected southern California and Nevada. Notable intermodel differences are again found in the estimated $R$ (MDA8, EAS, $20 \%)$, but they are overall lower than on 9 May $(<1.0 \mathrm{ppbv})$. The mean $R$ (MDA8, EAS, $20 \%$ ) at the two high $\mathrm{O}_{3}$ CASTNET sites ranges from 0.54 (STEM/C-IFS) to $0.86 \mathrm{ppbv}$ (STEM/RAQMS), with the mean $S_{\mathrm{O}_{3}}$ of $\sim 1.13$ at these sites based on the STEM/RAQMS runs (Fig. 18e-h). $R$ (MDA8, EAS, $100 \%$ ) from the STEM/RAQMS case is as high as $>6 \mathrm{ppbv}$ over southern California and Nevada. Compared to the spring
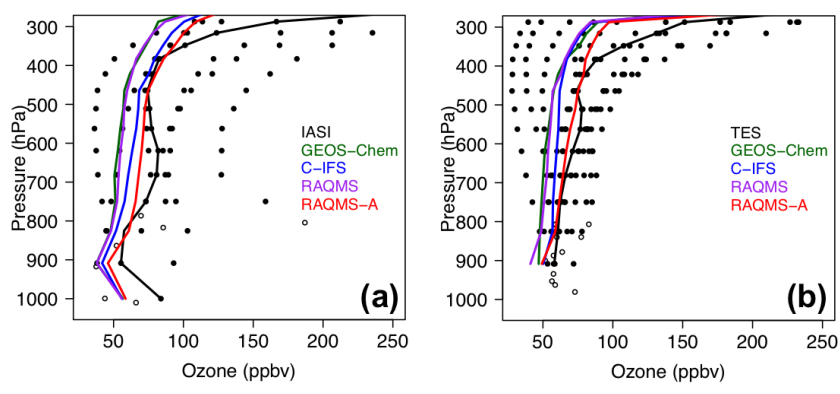

Figure 17. Same as Fig. 14, but for a case study of 10 June 2010.

event, $R$ (MDA8, EAS, $20 \%$ ) in the eastern US are discernable only over a limited region, due to weaker transport and stronger local chemical production/loss.

\section{Conclusions and suggestions on future directions}

In support of the HTAP phase 2 experiment that involved high-resolution global models and regional models' participation to advance the understanding of the pollutants' SR relationships in the Northern Hemisphere, we conducted a number of regional-scale STEM base and forward sensitivity simulations over NAM during May-June 2010. STEM's top and lateral chemical boundary conditions were downscaled from three global models' (i.e., GEOS-Chem, RAQMS, and ECMWF C-IFS) base and sensitivity simulations (in which the East Asian anthropogenic emissions were reduced by $20 \%$ ). Despite dilution along the great transport distance, the East Asian anthropogenic sources still had a distinguishable impact on the NAM surface $\mathrm{O}_{3}$, with the period-mean NAM $\mathrm{O}_{3}$ sensitivities to a $20 \%$ reduction of the East Asian anthropogenic emissions, i.e., $R\left(\mathrm{O}_{3}\right.$, EAS, $20 \%$ ), ranging from $\sim 0.24 \mathrm{ppbv}$ (STEM/C-IFS) to $\sim 0.34 \mathrm{ppbv}$ (STEM/RAQMS). The spatial patterns of the STEM surface $\mathrm{O}_{3}$ sensitivities over NAM overall resembled those from its corresponding boundary condition model, with regional/period-mean $R\left(\mathrm{O}_{3}\right.$, EAS, $\left.20 \%\right)$ differing slightly $(<10 \%)$ from its corresponding boundary condition model, which are smaller than those among its boundary condition models. The boundary condition models' 2-month mean $R\left(\mathrm{O}_{3}, \mathrm{EAS}, 20 \%\right)$ was $\sim 8 \%$ lower than the mean sensitivity estimated by eight global models. Therefore, choosing other global model outputs as STEM's boundary conditions may lead to different STEM $\mathrm{O}_{3}$ sensitivities. The biases and RMSEs in the simulated total $\mathrm{O}_{3}$, which differed significantly among models, can partially be due to the uncertainty in the bottom-up $\mathrm{NO}_{x}$ emission inputs according to the model comparison with the OMI $\mathrm{NO}_{2}$ columns, and future work on attributing the intermodel differences on process level is particularly important for better understanding the sources of uncertainties in the modeled total $\mathrm{O}_{3}$ and its source contribution. 


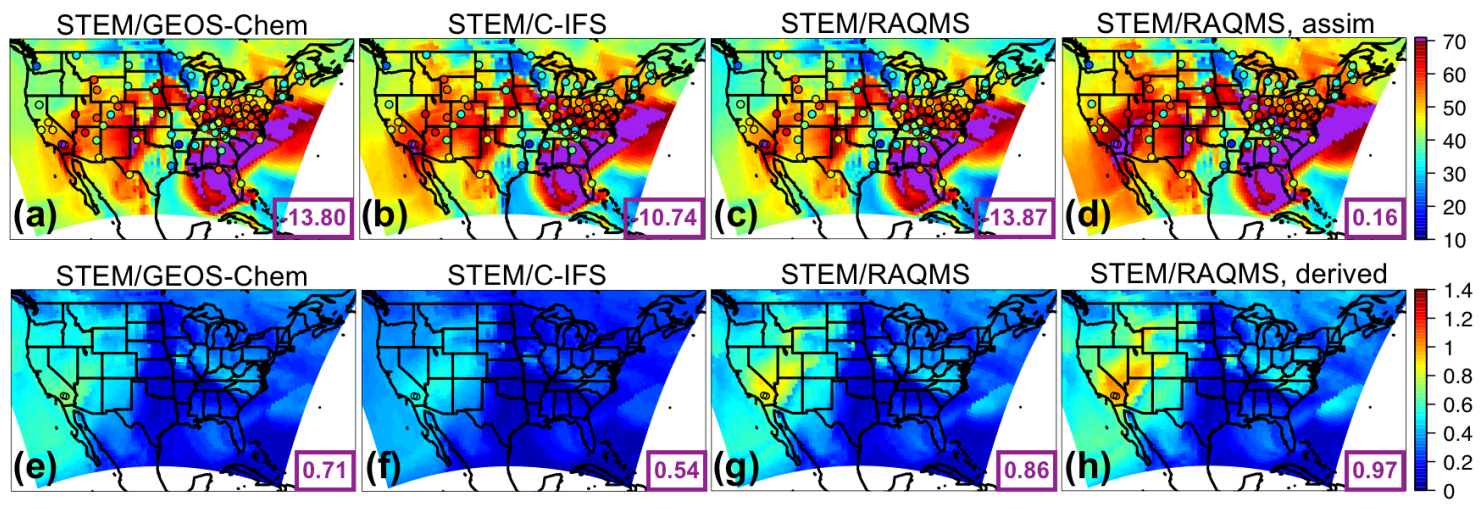

Figure 18. Same as Fig. 15, but for a case study of 10 June 2010. The CASTNET sites with $\mathrm{O}_{3}$ exceedances on this day are Converse Station and Joshua Tree NP in southern California.

The HTAP2 multi-model ensemble mean $R\left(\mathrm{O}_{3}\right.$, EAS, $20 \%$ ) values in 2010 were higher than the HTAP1 reported 2001 conditions, due to a number of reasons including the impacts of the growing East Asian anthropogenic emissions, the interannual variability in atmospheric circulation (i.e., stronger trans-Pacific transport in spring 2010 following an El Niño event), and the different experiment designs of HTAP1 and HTAP2. The GEOS-Chem $\mathrm{O}_{3}$ sensitivities in 2010 were also higher than the 2008-2009 conditions due to the increasing Asian emissions and the spring 2010 meteorological conditions that favored the trans-Pacific pollution transport. The GEOS-Chem sensitivity calculations indicate that the East Asian anthropogenic $\mathrm{NO}_{x}$ emissions mattered more than the other East Asian $\mathrm{O}_{3}$ precursors to the $\mathrm{NAM} \mathrm{O}_{3}$, qualitatively consistent with previous adjoint sensitivity calculations. Continued research is needed on temporal changes of emissions for different species and sectors in NAM and foreign countries as well as their impacts on the SR relationships. As emissions from various source sectors can differ by emitted altitudes and temporal profiles, efforts should also be placed to have the models timely update the height and temporal profiles of the emissions from various sectors.

An additional STEM simulation was performed in which the boundary conditions were downscaled from a RAQMS simulation without East Asian anthropogenic emissions (i.e., a $100 \%$ emission reduction) to assess the scalability of the mean $\mathrm{O}_{3}$ sensitivities to the size of the emission perturbation. The scalability was found to be spatially varying, ranging from 1.15-1.25 for column $\mathrm{O}_{3}$ in most US regions, which were overall $\sim 0.05$ higher than in the surface $\mathrm{O}_{3}$. Therefore, the full source contribution obtained by linearly scaling the NAM regional-mean $\mathrm{O}_{3}$ sensitivity to the $20 \%$ reduction in the East Asian emissions may be underestimated by at least $10 \%$. The underestimation in other seasons of the HTAP2 study period may be higher and will need to be quantified in future work. Moreover, motivated by Lapina et al. (2014), additional calculations will be conducted in future studies to explore the scalability of different $\mathrm{O}_{3}$ metrics in these cases. For future source attribution analysis, it is generally recommended to directly choose the suitable size of the emission perturbation based on the specific questions to address and to avoid linearly scaling $\mathrm{O}_{3}$ sensitivities that are based on other amounts of the perturbations.

The STEM $\mathrm{O}_{3}$ sensitivities to the East Asian anthropogenic emissions (based on three boundary condition models separately and averagely) were strong during 3-6 episodes in May-June 2010, following similar diurnal cycles as the total $\mathrm{O}_{3}$. Stronger East Asian anthropogenic pollution impacts were estimated during the observed $\mathrm{O}_{3}$ exceedances in the western US than on all days, especially over the highterrain rural/remote areas; in contrast, the East Asian anthropogenic pollution impacts were not as strong during $\mathrm{O}_{3}$ exceedances in other US regions. We emphasized the importance of saving model results hourly for conveniently calculating policy-relevant metrics as well as the usefulness of hourly sampling frequency of the planned geostationary satellites for better evaluating the impacts of the LRT events.

Based on model calculations, satellite $\mathrm{O}_{3}$ (TES, JPL-IASI, and AIRS), CO (TES and AIRS), and surface $\mathrm{O}_{3}$ observations on 9 May 2010, we showed the different influences from stratospheric $\mathrm{O}_{3}$ intrusions along with the transported East Asian pollution on $\mathrm{O}_{3}$ in the western and the eastern US. This event was further compared with a summer event on 10 June 2010. During both events, the unsatisfactory performance of free-running (i.e., without chemical data assimilation) global models would pose difficulties for regional models (regardless of their resolutions and other configurations, parameterization) for accurately simulating the surface $\mathrm{O}_{3}$ and its source contribution using boundary conditions downscaled from these model runs. Incorporating satellite (OMI and MLS) $\mathrm{O}_{3}$ data effectively improved the modeled $\mathrm{O}_{3}$. As chemical data assimilation techniques keep developing (Bocquet et al., 2015), several HTAP2 participating global models have already been able to assimilate single- or multi-constitute satellite atmospheric composition data (e.g., 
Miyazaki et al., 2012; Parrington et al., 2008, 2009; Huang et al., 2015; Inness et al., 2015; Flemming et al., 2017). Comparing the performance of the assimilated fields from different models and making the global model assimilated chemical fields in the suitable format for being used as boundary conditions would be very beneficial for future regional modeling as well as for better interpreting the pollutants' distributions, especially during the exceptional events. Meanwhile, efforts should also be devoted to advancing and applying higher-resolution regional-scale modeling and chemical data assimilation. Furthermore, although satellite observations have been applied to improve the estimated US background $\mathrm{O}_{3}$ (e.g., Huang et al., 2015), the use of satellite (and/or other types of) observations to improve SR relationship studies also needs to be explored. Some of the possible methods include (1) the combination of data assimilation and the tagging approach and (2) the introduction of observationconstrained emission estimates in the emission perturbation analyses.

Data availability. The model outputs in HTAP2 standard format were submitted to the AeroCom database following guidelines at http://iek8wikis.iek.fz-juelich.de/HTAPWiki/ HTAP-2-data-submission and can be obtained upon request.

In situ observations data can be accessed at http://epa.gov/ castnet/javaweb/index.html and http://www.eanet.asia/.

Satellite data can be accessed at https://tes.jpl.nasa.gov/data/, https://acdisc.gesdisc.eosdis.nasa.gov/data/Aqua_AIRS_Level3/, and http://www.temis.nl/airpollution/no2.html. IASI retrievals that are achieved at JPL can be obtained by contacting Vivienne H. Payne at vivienne.h.payne@jpl.nasa.gov.

\section{The Supplement related to this article is available online at doi:10.5194/acp-17-5721-2017-supplement.}

Competing interests. The authors declare that they have no conflict of interest.

Disclaimer. Part of this research was carried out at the Jet Propulsion Laboratory, California Institute of Technology, under contract to the National Aeronautics and Space Administration. Reference herein to any specific commercial product, process or service by trade name, trademark, manufacturer or otherwise does not constitute or imply its endorsement by the United States government or the Jet Propulsion Laboratory, California Institute of Technology. The views, opinions, and findings contained in this report are those of the author(s) and should not be construed as an official National Oceanic and Atmospheric Administration or U.S. government position, policy, or decision.
Acknowledgements. Technical support from Anna Carlin Benedictow, Brigitte Koffi, Jan Griesfeller, and Michael Schulz regarding the formatting and submitting of the modeling products to the AeroCom is acknowledged. Min Huang thanks the research resources at the University of Iowa and JPL/Caltech that supported this study as well as the travel funding from the US EPA for attending the related HTAP2 workshops. Daven K. Henze and Yanko Davila recognize support from NASA AQAST. Frank J. Dentener acknowledges support from the Administrative Arrangement. We also acknowledge the feedbacks from Gail Tonnesen, two anonymous reviewers, and Meiyun Lin on earlier versions of this paper, which helped improve its quality.

Edited by: C. Hogrefe

Reviewed by: G. S. Tonnesen and two anonymous referees

\section{References}

Allen, D. J., Pickering, K. E., Pinder, R. W., Henderson, B. H., Appel, K. W., and Prados, A.: Impact of lightning-NO on eastern United States photochemistry during the summer of 2006 as determined using the CMAQ model, Atmos. Chem. Phys., 12, 1737-1758, doi:10.5194/acp-12-1737-2012, 2012.

Ambrose, J. L., Reidmiller, D. R., and Jaffe, D. A.: Causes of high $\mathrm{O}_{3}$ in the lower free troposphere over the Pacific Northwest as observed at the Mt. Bachelor Observatory, Atmos. Environ., 45, 5302-5315, doi:10.1016/j.atmosenv.2011.06.056, 2011.

Anderson, D. C., Loughner, C. P., Diskin, G., Weinheimer, A., Canty, T. P., Salawitch, R. J., Worden, H. M., Fried, A., Mikoviny, T., Wisthaler, A., and Dickerson, R. R.: Measured and modeled $\mathrm{CO}$ and $\mathrm{NO}_{y}$ in DISCOVER-AQ: An evaluation of emissions and chemistry over the eastern US, Atmos. Environ., 96, 78-87, doi:10.1016/j.atmosenv.2014.07.004, 2014.

Anenberg, S. C., Horowitz, L. W., Tong, D. Q., and West, J. J.: An estimate of the global burden of anthropogenic ozone and fine particulate matter on premature human mortality using atmospheric modeling, Environ. Health Persp., 118, 1189-1195, 2010.

Avnery, S., Mauzerall, D. L., Liu, J., and Horowitz, L. W.: Global Crop Yield Reductions due to Surface Ozone Exposure: 1. Year 2000 Crop Production Losses and Economic Damage, Atmos. Environ., 45, 2284-2296, 2011a.

Avnery, S., Mauzerall, D. L., Liu, J., and Horowitz, L. W.: Global Crop Yield Reductions due to Surface Ozone Exposure: 2. Year 2030 Potential Crop Production Losses and Economic Damage under Two Scenarios of $\mathrm{O}_{3}$ Pollution, Atmos. Environ., 45, 2297-2309, 2011b.

Beer, R.: TES on the Aura Mission: Scientific Objectives, Measurements, and Analysis Overview, IEEE T. Geosci. Remote Sens., 44, 1102-1105, 2006.

Beer, R., Glavich, T. A., and Rider, D. M.: Tropospheric emission spectrometer for the Earth Observing System's Aura satellite, Appl. Optics, 40, 2356-2367, 2001.

Bian, J., Gettelman, A., Chen, H., and Pan, L. L.: Validation of satellite ozone profile retrievals using Beijing ozonesonde data, J. Geophys. Res., 112, D06305, doi:10.1029/2006JD007502, 2007.

Bocquet, M., Elbern, H., Eskes, H., Hirtl, M., Žabkar, R., Carmichael, G. R., Flemming, J., Inness, A., Pagowski, M., Pérez 
Camaño, J. L., Saide, P. E., San Jose, R., Sofiev, M., Vira, J., Baklanov, A., Carnevale, C., Grell, G., and Seigneur, C.: Data assimilation in atmospheric chemistry models: current status and future prospects for coupled chemistry meteorology models, Atmos. Chem. Phys., 15, 5325-5358, doi:10.5194/acp-15-53252015, 2015.

Boersma, K. F., Braak, R., and van der A, R. J.: Dutch OMI $\mathrm{NO}_{2}$ (DOMINO) data product v2.0 HE5 data file user manual, available at: http://www.temis.nl/docs/OMI_NO2_HE5_2. 0_2011.pdf (last access: February 2017), 2011a.

Boersma, K. F., Eskes, H. J., Dirksen, R. J., van der A, R. J., Veefkind, J. P., Stammes, P., Huijnen, V., Kleipool, Q. L., Sneep, M., Claas, J., Leitão, J., Richter, A., Zhou, Y., and Brunner, D.: An improved tropospheric $\mathrm{NO}_{2}$ column retrieval algorithm for the Ozone Monitoring Instrument, Atmos. Meas. Tech., 4, 19051928, doi:10.5194/amt-4-1905-2011, 2011 b.

Bowman, K. and Henze, D. K.: Attribution of direct ozone radiative forcing to spatially resolved emissions, Geophys. Res. Lett., 39, L22704, doi:10.1029/2012GL053274, 2012.

Bowman, K. W., Rodgers, C. D., Kulawik, S. S., Worden, J., Sarkissian, E., Osterman, G., Steck, T., Lou, M., Eldering, A., Shephard, M., Worden, H., Lampel, M., Clough, S., Brown, P., Rinsland, C., Gunson, M., and Beer, R.: Tropospheric Emission Spectrometer: Retrieval method and error analysis, IEEE T. Geosci. Remote Sens., 44, 1297-1307, doi:10.1109/TGRS.2006.871234, 2006.

Brioude, J., Angevine, W. M., Ahmadov, R., Kim, S.-W., Evan, S., McKeen, S. A., Hsie, E.-Y., Frost, G. J., Neuman, J. A., Pollack, I. B., Peischl, J., Ryerson, T. B., Holloway, J., Brown, S. S., Nowak, J. B., Roberts, J. M., Wofsy, S. C., Santoni, G. W., Oda, T., and Trainer, M.: Top-down estimate of surface flux in the Los Angeles Basin using a mesoscale inverse modeling technique: assessing anthropogenic emissions of $\mathrm{CO}, \mathrm{NO}_{x}$ and $\mathrm{CO}_{2}$ and their impacts, Atmos. Chem. Phys., 13, 3661-3677, doi:10.5194/acp13-3661-2013, 2013.

Brown-Steiner, B. and Hess, P.: Asian influence on surface ozone in the United States: A comparison of chemistry, seasonality, and transport mechanisms, J. Geophys. Res., 116, D17309, doi:10.1029/2011JD015846, 2011.

Cai, C., Kelly, J. T., Avise, J. C., Kaduwela, A. P., and Stockwell, W. R.: Photochemical Modeling in California with Two Chemical Mechanisms: Model Intercomparison and Response to Emission Reductions, J. Air Waste Manage. Assoc., 61, 559-572, doi:10.3155/1047-3289.61.5.559, 2011.

Canty, T. P., Hembeck, L., Vinciguerra, T. P., Anderson, D. C., Goldberg, D. L., Carpenter, S. F., Allen, D. J., Loughner, C. P., Salawitch, R. J., and Dickerson, R. R.: Ozone and $\mathrm{NO}_{x}$ chemistry in the eastern US: evaluation of CMAQ/CB05 with satellite (OMI) data, Atmos. Chem. Phys., 15, 10965-10982, doi:10.5194/acp-15-10965-2015, 2015.

Carmichael, G. R., Tang, Y., Kurata, G., Uno, I., Streets, D. G., Thongboonchoo, N., Woo, J. H., Guttikunda, S., White, A., Wang, T., Blake, D. R., Atlas, E., Fried, A., Potter, B., Avery, M. A., Sachse, G. W., Sandholm, S. T., Kondo, Y., Talbot, R. W., Bandy, A., Thorton, D., and Clarke, A. D.: Evaluating regional emission estimates using the TRACE-P observations, J. Geophys. Res., 108, 8810, doi:10.1029/2002JD003116, 2003a.

Carmichael, G. R., Tang, Y., Kurata, G., Uno, I., Streets, D., Woo, J. H., Huang, H., Yienger, J., Lefer, B., Shetter, R., Blake, D., Atlas,
E., Fried, A., Apel, E., Eisele, F., Cantrell, C., Avery, M., Barrick, J., Sachse, G., Brune, W., Sandholm, S., Kondo, Y., Singh, H., Talbot, R., Bandy, A., Thorton, D., Clarke, A., and Heikes, B.: Regional-scale chemical transport modeling in support of the analysis of observations obtained during the TRACE-P experiment, J. Geophys. Res., 108, 8823, doi:10.1029/2002JD003117, 2003b.

Carter, W. P. L.: Documentation of the SAPRC-99 chemical mechanism for VOC Reactivity Assessment, final report to California Air Resources Board, Contract No. 92-329 and 95-308, 2000.

Cooper, O. R., Parrish, D. D., Stohl, A., Trainer, M., Nédélec, P., Thouret, V., Cammas, J. P., Oltmans, S. J., Johnson, B. J., Tarasick, D., Leblanc, T., McDermid, I. S., Jaffe, D., Gao, R., Stith, J., Ryerson, T., Aikin, K., Campos, T., Weinheimer, A., and Avery, M. A.: Increasing springtime ozone mixing ratios in the free troposphere over western North America, Nature, 463, 344-348, doi:10.1038/nature08708, 2010.

Cooper, O. R., Oltmans, S. J., Johnson, B. J., Brioude, J., Angevine, W., Trainer, M., Parrish, D. D., Ryerson, T. R., Pollack, I., Cullis, P. D., Ives, M. A., Tarasick, D. W., Al-Saadi, J., and Stajner, I.: Measurement of western U.S. baseline ozone from the surface to the tropopause and assessment of downwind impact regions, J. Geophys. Res., 116, D00V03, doi:10.1029/2011JD016095, 2011.

Cooper, O.: Western NA Performance Evaluation for HTAP2, HTAP2 workshop, Potsdam, Germany, 2016.

Crippa, M., Janssens-Maenhout, G., Dentener, F., Guizzardi, D., Sindelarova, K., Muntean, M., Van Dingenen, R., and Granier, C.: Forty years of improvements in European air quality: regional policy-industry interactions with global impacts, Atmos. Chem. Phys., 16, 3825-3841, doi:10.5194/acp-16-3825-2016, 2016.

Emmons, L. K., Hess, P. G., Lamarque, J.-F., and Pfister, G. G.: Tagged ozone mechanism for MOZART-4, CAM-chem and other chemical transport models, Geosci. Model Dev., 5, 15311542, doi:10.5194/gmd-5-1531-2012, 2012.

Eskes, H. J. and Boersma, K. F.: Averaging kernels for DOAS totalcolumn satellite retrievals, Atmos. Chem. Phys., 3, 1285-1291, doi:10.5194/acp-3-1285-2003, 2003.

Fiore, A. M., Dentener, F. J., Wild, O., Cuvelier, C., Schultz, M. G., Hess, P., Textor, C., Schulz, M., Doherty, R. M., Horowitz, L. W., MacKenzie, I. A., Sanderson, M. G., Shindell, D. T., Stevenson, D. S., Szopa, S., Van Dingenen, R., Zeng, G., Atherton, C., Bergmann, D., Bey, I., Carmichael, G., Collins, W. J., Duncan, B. N., Faluvegi, G., Folberth, G., Gauss, M., Gong, S., Hauglustaine, D., Holloway, T., Isaksen, I. S. A., Jacob, D. J., Jonson, J. E., Kaminski, J. W., Keating, T. J., Lupu, A., Marmer, E., Montanaro, V., Park, R. J., Pitari, G., Pringle, K. J., Pyle, J. A., Schroeder, S., Vivanco, M. G., Wind, P., Wojcik, G., Wu, S., and Zuber, A.: Multimodel estimates of intercontinental source receptor relationships for ozone pollution, J. Geophys. Res., 114, D04301, doi:10.1029/2008JD010816, 2009.

Fiore, A. M., Oberman, J. T., Lin, M. Y., Zhang, L., Clifton, O. E., Jacob, D. J., Naik, V., Horowitz, L. W., Pinto, J. P., and Milly, G. P.: Estimating North American background ozone in U.S. surface air with two independent global models: Variability, uncertainties, and recommendations, Atmos. Environ., 96, 284-300, doi:10.1016/j.atmosenv.2014.07.045, 2014.

Flemming, J., Huijnen, V., Arteta, J., Bechtold, P., Beljaars, A., Blechschmidt, A.-M., Diamantakis, M., Engelen, R. J., Gaudel, 
A., Inness, A., Jones, L., Josse, B., Katragkou, E., Marecal, V., Peuch, V.-H., Richter, A., Schultz, M. G., Stein, O., and Tsikerdekis, A.: Tropospheric chemistry in the Integrated Forecasting System of ECMWF, Geosci. Model Dev., 8, 975-1003, doi:10.5194/gmd-8-975-2015, 2015.

Flemming, J., Benedetti, A., Inness, A., Engelen, R. J., Jones, L., Huijnen, V., Remy, S., Parrington, M., Suttie, M., Bozzo, A., Peuch, V.-H., Akritidis, D., and Katragkou, E.: The CAMS interim Reanalysis of Carbon Monoxide, Ozone and Aerosol for 2003-2015, Atmos. Chem. Phys., 17, 1945-1983, doi:10.5194/acp-17-1945-2017, 2017.

Galmarini, S., Hogrefe, C., Brunner, D., Makar, P., and Baklanov, A.: Preface to the AQMEII p2 Special issue, Atmos. Environ., $115,340-344,2015$.

Galmarini, S., Koffi, B., Solazzo, E., Keating, T., Hogrefe, C., Schulz, M., Benedictow, A., Griesfeller, J. J., JanssensMaenhout, G., Carmichael, G., Fu, J., and Dentener, F.: Technical note: Coordination and harmonization of the multi-scale, multi-model activities HTAP2, AQMEII3, and MICS-Asia3: simulations, emission inventories, boundary conditions, and model output formats, Atmos. Chem. Phys., 17, 1543-1555, doi:10.5194/acp-17-1543-2017, 2017.

Geddes, J. A., Heald, C. L., Silva, S. J., and Martin, R. V.: Land cover change impacts on atmospheric chemistry: simulating projected large-scale tree mortality in the United States, Atmos. Chem. Phys., 16, 2323-2340, doi:10.5194/acp-16-2323-2016, 2016.

Gery, M. W., Whitten, G. Z., Killus, J. P., and Dodge, M. C.: A photochemical kinetics mechanism for urban and regional scale computer modeling, J. Geophys. Res., 94, 12925-12956, doi:10.1029/JD094iD10p12925, 1989.

Granier, C., Lamarque, J. F., Mieville, A., Muller, J. F., Olivier, J., Orlando, J., Peters, J., Petron, G., Tyndall, G., and Wallens, S.: POET, a database of surface emissions of ozone precursors, available at: http://www.aero.jussieu.fr/projet/ACCENT/POET. php, 2005

Gratz, L. E., Jaffe, D. A., and Hee, J. R.: Causes of increasing ozone and decreasing carbon monoxide in springtime at the Mt. Bachelor Observatory from 2004 to 2013, Atmos. Environ., 109, 323 330, doi:10.1016/j.atmosenv.2014.05.076, 2014

Guenther, A. B., Jiang, X., Heald, C. L., Sakulyanontvittaya, T., Duhl, T., Emmons, L. K., and Wang, X.: The Model of Emissions of Gases and Aerosols from Nature version 2.1 (MEGAN2.1): an extended and updated framework for modeling biogenic emissions, Geosci. Model Dev., 5, 1471-1492, doi:10.5194/gmd-51471-2012, 2012.

Henze, D. K., Hakami, A., and Seinfeld, J. H.: Development of the adjoint of GEOS-Chem, Atmos. Chem. Phys., 7, 2413-2433, doi:10.5194/acp-7-2413-2007, 2007.

Hilsenrath, E. and Chance, K.: NASA ups the TEMPO on monitoring air pollution, Earth Obs., 25, 10-15, 2013.

Hogrefe, C., Isukapalli, S., Tang, X., Georgopoulos, P., He, S., Zalewsky, E., Hao, W., Ku, J., Key, T., and Sistla, G.: Impact of biogenic emission uncertainties on the simulated response of ozone and fine Particulate Matter to anthropogenic emission reductions, J. Air Waste Manage., 61, 92-108, 2011.

Huang, M., Carmichael, G. R., Adhikary, B., Spak, S. N., Kulkarni, S., Cheng, Y. F., Wei, C., Tang, Y., Parrish, D. D., Oltmans, S. J., D’Allura, A., Kaduwela, A., Cai, C., Weinheimer, A. J., Wong,
M., Pierce, R. B., Al-Saadi, J. A., Streets, D. G., and Zhang, Q. Impacts of transported background ozone on California air quality during the ARCTAS-CARB period - a multi-scale modeling study, Atmos. Chem. Phys., 10, 6947-6968, doi:10.5194/acp-106947-2010, 2010.

Huang, M., Carmichael, G. R., Chai, T., Pierce, R. B., Oltmans, S. J., Jaffe, D. A., Bowman, K. W., Kaduwela, A., Cai, C., Spak, S. N., Weinheimer, A. J., Huey, L. G., and Diskin, G. S.: Impacts of transported background pollutants on summertime western US air quality: model evaluation, sensitivity analysis and data assimilation, Atmos. Chem. Phys., 13, 359-391, doi:10.5194/acp-13359-2013, 2013a.

Huang, M., Bowman, K. W., Carmichael, G. R., Pierce, R. B., Worden, H. M., Luo, M., Cooper, O. R., Pollack, I. B., Ryerson, T. B., and Brown, S. S.: Impact of southern California anthropogenic emissions on ozone pollution in the mountain states, J. Geophys. Res., 118, 12784-12803, doi:10.1002/2013JD020205, 2013 b.

Huang, M., Bowman, K. W., Carmichael, G. R., Chai, T., Pierce, R. B., Worden, J. R., Luo, M., Pollack, I. B., Ryerson, T. B., Nowak, J. B., Neuman, J. A., Roberts, J. M., Atlas, E. L., and Blake, D. R.: Changes in nitrogen oxides emissions in California during 2005-2010 indicated from top-down and bottomup emission estimates, J. Geophys. Res., 119, 12928-12952, doi:10.1002/2014JD022268, 2014.

Huang, M., Bowman, K. W., Carmichael, G. R., Lee, M., Chai, T., Spak, S. N., Henze, D. K., Darmenov, A. S., and da Silva, A. M.: Improved Western US Background Ozone Estimates via Constraining Nonlocal and Local Source Contributions using Aura TES and OMI Observations, J. Geophys. Res., 120, 3572-3592, doi:10.1002/2014JD022993, 2015.

Huang, M., Carmichael, G. R., Crawford, J. H., Wisthaler, A., Zhan, X., Hain, C. R., Lee, P., and Guenther, A. B.: Linkages between land initialization of the NASA-Unified WRF $\mathrm{v} 7$ and biogenic isoprene emission estimates during the SEAC ${ }^{4} \mathrm{RS}$ and DISCOVER-AQ airborne campaigns, Geosci. Model Dev. Discuss., doi:10.5194/gmd-2017-13, in review, 2017.

Inness, A., Blechschmidt, A.-M., Bouarar, I., Chabrillat, S., Crepulja, M., Engelen, R. J., Eskes, H., Flemming, J., Gaudel, A., Hendrick, F., Huijnen, V., Jones, L., Kapsomenakis, J., Katragkou, E., Keppens, A., Langerock, B., de Mazière, M., Melas, D., Parrington, M., Peuch, V. H., Razinger, M., Richter, A., Schultz, M. G., Suttie, M., Thouret, V., Vrekoussis, M., Wagner, A., and Zerefos, C.: Data assimilation of satelliteretrieved ozone, carbon monoxide and nitrogen dioxide with ECMWF's Composition-IFS, Atmos. Chem. Phys., 15, 52755303, doi:10.5194/acp-15-5275-2015, 2015.

Jaffe, D. A.: Relationship between surface and free tropospheric ozone in the Western U.S., Environ. Sci. Technol., 45, 432-438, doi:10.1021/es1028102, 2011.

Janssens-Maenhout, G., Crippa, M., Guizzardi, D., Dentener, F., Muntean, M., Pouliot, G., Keating, T., Zhang, Q., Kurokawa, J., Wankmüller, R., Denier van der Gon, H., Kuenen, J. J. P., Klimont, Z., Frost, G., Darras, S., Koffi, B., and Li, M.: HTAP_v2.2: a mosaic of regional and global emission grid maps for 2008 and 2010 to study hemispheric transport of air pollution, Atmos. Chem. Phys., 15, 11411-11432, doi:10.5194/acp15-11411-2015, 2015. 
Jacob, D. J., Logan, J. A., and Murti, P. P.: Effect of rising Asian emissions on surface ozone in the United States, Geophys. Res. Lett., 26, 2175-2178, doi:10.1029/1999GL900450, 1999.

Jerret, M., Burnett, R. T., Popo III, C. A., Ito, K., Thurston, G., Krewski, D., Shi, Y., Calle, E., and Thun, M.: Long-Term Ozone Exposure and Mortality, New Engl. J. Med., 360, 1085-1096, doi:10.1056/NEJMoa0803894, 2009.

Kaiser, J. W., Heil, A., Andreae, M. O., Benedetti, A., Chubarova, N., Jones, L., Morcrette, J.-J., Razinger, M., Schultz, M. G., Suttie, M., and van der Werf, G. R.: Biomass burning emissions estimated with a global fire assimilation system based on observed fire radiative power, Biogeosciences, 9, 527-554, doi:10.5194/bg-9-527-2012, 2012.

Kalnay, E., Kanamitsu, M., Kistler, R., Collins, W., Deaven, D., Gandin, L., Iredell, M., Saha, S., White, G., Woollen, J., Zhu, Y., Chelliah, M., Ebisuzaki, W., Higgins, W., Janowiak, J., Mo, K. C., Ropelewski, C., Wang, J., Leetmaa, A., Reynolds, R., Jenne, R., and Joseph, D.: The NCEP/NCAR 40-Year Reanalysis Project, B. Am. Meteorol. Soc., 77, 437-471, 1996.

Kim, S.-W., McDonald, B. C., Baidar, S., Brown, S. S., Dube, B., Ferrare, R. A., Frost, G. J., Harley, R. A., Holloway, J. S., Lee, H.-J., McKeen, S. A., Neuman, J. A., Nowak, J. B., Oetjen, H., Ortega, I., Pollack, I. B., Roberts, J. M., Ryerson, T. B., Scarino, A. J., Senff, C. J., Thalman, R., Trainer, M., Volkamer, R., Wagner, N., Washenfelder, R. A., Waxman, E., and Young, C. J.: Modeling the weekly cycle of $\mathrm{NO}_{x}$ and $\mathrm{CO}$ emissions and their impacts on $\mathrm{O}_{3}$ in the Los Angeles-South Coast Air Basin during the CalNex 2010 field campaign, J. Geophys. Res.-Atmos., 121, 1340-1360, doi:10.1002/2015JD024292, 2016.

Koffi, B., Dentener, F., Janssens-Maenhout, G., Guizzardi, D., Crippa, M., Diehl, T., Galmarini, S., and Solazzo, E.: Hemispheric Transport Air Pollution (HTAP): Specification of the HTAP2 experiments - Ensuring harmonized modelling, EUR 28255 EN - Scientific and Technical Research Reports, doi:10.2788/725244, 2016.

Langford, A. O., Brioude, J., Cooper, O. R., Senff, C. J., Alvarez II, R. J., Hardesty, R. M., Johnson, B. J., and Oltmans, S. J.: Stratospheric influence on surface ozone in the Los Angeles area during late spring and early summer of 2010, J. Geophys. Res.Atmos., 117, D00V06, doi:10.1029/2011JD016766, 2011.

Lapina, K., Henze, D. K., Milford, J. B., Huang, M., Lin, M., Fiore, A. M., Carmichael, G., Pfister, G. G., and Bowman, K.: Assessment of source contributions to seasonal vegetative exposure to ozone in the U.S., J. Geophys. Res.-Atmos., 119, 324-340, doi:10.1002/2013JD020905, 2014.

Levelt, P. F., Hilsenrath, E., Leppelmeier, G. W., van den Oord, G. H. J., Bhartia, P. K., Tamminen, J., de Haan, J. F., and Veefkind, J. P.: Science Objectives of the Ozone Monitoring Instrument, IEEE T. Geosci. Remote Sens., 44, 1199-1208, 2006.

Li, M., Zhang, Q., Kurokawa, J.-I., Woo, J.-H., He, K., Lu, Z., Ohara, T., Song, Y., Streets, D. G., Carmichael, G. R., Cheng, Y., Hong, C., Huo, H., Jiang, X., Kang, S., Liu, F., Su, H., and Zheng, B.: MIX: a mosaic Asian anthropogenic emission inventory under the international collaboration framework of the MICS-Asia and HTAP, Atmos. Chem. Phys., 17, 935-963, doi:10.5194/acp17-935-2017, 2017.

Lin, M., Holloway, T., Carmichael, G. R., and Fiore, A. M.: Quantifying pollution inflow and outflow over East Asia in spring with regional and global models, Atmos. Chem. Phys., 10, 42214239, doi:10.5194/acp-10-4221-2010, 2010.

Lin, M., Fiore, A. M., Horowitz, L. W., Cooper, O. R., Naik, V., Holloway, J., Johnson, B. J., Middlebrook, A., Oltmans, S. J., Pollack, I. B., Ryerson, T. B., Warner, J. X., Wiedinmyer, C., Wilson, J., and Wyman, B.: Transport of Asian ozone pollution into surface air over the western United States in spring, J. Geophys. Res., 117, D00V07, doi:10.1029/2011JD016961, 2012a.

Lin, M., Fiore, A., Cooper, O. R. R., Horowitz, L. W., Langford, A. O. O., Levy II, H., Johnson, B. J., Naik, V., Oltmans, S. J., and Senff, C. J.: Springtime high surface ozone events over the western United States: Quantifying the role of stratospheric intrusions, J. Geophys. Res., 117, D00V22, doi:10.1029/2012JD018151, 2012b.

Lin, M., Horowitz, L. W., Oltmans, S. J., Fiore, A. M., and Fan, S.: Tropospheric ozone trends at Manna Loa Observatory tied to decadal climate variability, Nat. Geosci., 7, 136-143, doi:10.1038/NGEO2066, 2014.

Lin, M., Horowitz, L. W., Cooper, O. R., Tarasick, D., Conley, S., Iraci, L. T., Johnson, B., Leblanc, T., Petropavlovskikh, I., and Yates, E. L.: Revisiting the evidence of increasing springtime ozone mixing ratios in the free troposphere over western North America, Geophys. Res. Lett., 42, 8719-8728, doi:10.1002/2015GL065311, 2015.

Lin, M., Horowitz, L. W., Payton, R., Fiore, A. M., and Tonnesen, G.: US surface ozone trends and extremes from 1980 to 2014: quantifying the roles of rising Asian emissions, domestic controls, wildfires, and climate, Atmos. Chem. Phys., 17, $2943-$ 2970, doi:10.5194/acp-17-2943-2017, 2017.

Liu, F., Zhang, Q., van der A, R. J., Zheng, B., Tong, D., Yan, L., Zheng, Y., and He, K.: Recent reduction in $\mathrm{NO}_{x}$ emissions over China: Synthesis of satellite observations and emission inventories, Environ. Res. Lett., 11, 114002, doi:10.1088/17489326/11/11/114002, 2016.

Livesey, N. J., Filipiak, M. J., Froidevaux, L., Read, W. G., Lambert, A., Santee, M. L., Jiang, J. H., Pumphrey, H. C., Waters, J. W., Cofield, R. E., Cuddy, D. T., Daffer, W. H., Drouin, B. J., Fuller, R. A., Jarnot, R. F., Jiang, Y. B., Knosp, B. W., Li, Q. B., Perun, V. S., Schwartz, M. J., Snyder, W. V., Stek, P. C., Thurstans, R. P., Wagner, P. A., Avery, M., Browell, E. V., Cammas, J.-P., Christensen, L. E., Diskin, G. S., Gao, R.-S., Jost, H.-J., Loewenstein, M., Lopez, J. D., Nedelec, P., Osterman, G. B., Sachse, G. W., and Webster, C. R.: Validation of Aura Microwave Limb Sounder $\mathrm{O}_{3}$ and $\mathrm{CO}$ observations in the upper troposphere and lower stratosphere, J. Geophys. Res., 113, D15S02, doi:10.1029/2007JD008805, 2008.

Luecken, D. J., Phillips, S., Sarwar, G., and Jang, C.: Effects of using the CB05 vs. SAPRC99 vs. CB4 chemical mechanism on model predictions, Ozone and gas-phase photochemical precursor concentrations, Atmos. Environ., 42, 5805-5820, doi:10.1016/j.atmosenv.2007.08.056, 2008.

Maas, R. and Grennfelt, P. (Eds.): Towards Cleaner Air Scientific Assessment Report 2016, EMEP Steering Body and Working Group on Effects of the Convention on LongRange Transboundary Air Pollution, Oslo, available at: http://www.unece.org/fileadmin/DAM/env/lrtap/ExecutiveBody/ 35th_session/CLRTAP_Scientific_Assessment_Report_-_ Final_20-5-2016.pdf (last access: February 2017), 2016. 
Madronich, S., Flocke, S., Zeng, J., Petropavlovskikh, I., and LeeTaylor, J.: The Tropospheric Ultra-violet Visible (TUV) model Manual, available at: https://www2.acom.ucar.edu/modeling/ tropospheric-ultraviolet-and-visible-tuv-radiation-model (last access: February 2017), 2002.

Mauzerall, D. L. and Wang, X.: Protecting Agricultural Crops from the Effects of Tropospheric Ozone Exposure: Reconciling Science and Standard Setting in the United States, Europe and Asia, Annu. Rev. Energ. Env., 26, 237-268, 2001.

McDonald-Buller, E. C., Elena, C., Allen, D. T., Brown, N., Jacob, D. J., Jaffe, D., Kolb, C. E., Lefohn, A. S., Oltmans, S., Parrish, D. D., Yarwood, G., and Zhang, L.: Establishing policy relevant background (PRB) ozone concentrations in the United States, Environ. Sci. Technol., 45, 9484-9497, 2011.

Meijer, E. W., van Velthoven, P. F. J., Brunner, D. W., Huntrieser, H., and Kelder, H.: Improvement and evaluation of the parameterization of nitrogen oxide production by lightning, Phys. Chem. Earth Pt. C, 26, 577-583, 2001.

Mesinger, F., DiMego, G., Kalnay, E., Mitchell, K., Shafran, P. C., Ebisuzaki, W., Jovic, D., Woollen, J., Rogers, E., Berbery, E. H., Ek, M. B., Fan, Y., Grumbine, R., Higgins, W., Li, H., Lin, Y., Manikin, G., Parrish, D., and Shi, W.: North American Regional Reanalysis, B. Am. Meteorol. Soc., 87, 343-360, doi:10.1175/BAMS-87-3-343, 2006.

Miyazaki, K., Eskes, H. J., Sudo, K., Takigawa, M., van Weele, M., and Boersma, K. F.: Simultaneous assimilation of satellite $\mathrm{NO}_{2}$, $\mathrm{O}_{3}, \mathrm{CO}$, and $\mathrm{HNO}_{3}$ data for the analysis of tropospheric chemical composition and emissions, Atmos. Chem. Phys., 12, 95459579, doi:10.5194/acp-12-9545-2012, 2012.

Monks, P. S., Archibald, A. T., Colette, A., Cooper, O., Coyle, M., Derwent, R., Fowler, D., Granier, C., Law, K. S., Mills, G. E., Stevenson, D. S., Tarasova, O., Thouret, V., von Schneidemesser, E., Sommariva, R., Wild, O., and Williams, M. L.: Tropospheric ozone and its precursors from the urban to the global scale from air quality to short-lived climate forcer, Atmos. Chem. Phys., 15, 8889-8973, doi:10.5194/acp-15-8889-2015, 2015.

Murray, L. T., D. J. Jacob, J. A. Logan, R. C. Hudman, and Koshak, W. J.: Optimized regional and interannual variability of lightning in a global chemical transport model constrained by LIS/OTD satellite data, J. Geophys. Res., 117, D20307, doi:10.1029/2012JD017934, 2012.

National Research Council: global sources of local pollution-An Assessment of Long-Range Transport of Key Air Pollutants to and from the United States, 35-66, available at: http://books.nap. edu/openbook.php?record_id=12743\&page=35, 2009.

Neuman, J. A., Trainer, M., Aikin, K. C., Angevine, W. M., Brioude, J., Brown, S. S., de Gouw, J. A., Dube, W. P., Flynn, J. H., Graus, M., Holloway, J. S., Lefer, B. L., Nedelec, P., Nowak, J. B., Parrish, D. D., Pollack, I. B., Roberts, J. M., Ryerson, T. B., Smit, H., Thouret, V., and Wagner, N. L.: Observations of ozone transport from the free troposphere to the Los Angeles basin, J. Geophys. Res.-Atmos., 117, D00V09, doi:10.1029/2011JD016919, 2012.

Oetjen, H., Payne, V. H., Kulawik, S. S., Eldering, A., Worden, J., Edwards, D. P., Francis, G. L., Worden, H. M., Clerbaux, C., Hadji-Lazaro, J., and Hurtmans, D.: Extending the satellite data record of tropospheric ozone profiles from Aura-TES to MetOp-IASI: characterisation of optimal estimation retrievals, Atmos. Meas. Tech., 7, 4223-4236, doi:10.5194/amt-7-42232014, 2014.
Oetjen, H., Payne, V. H., Neu, J. L., Kulawik, S. S., Edwards, D. P., Eldering, A., Worden, H. M., and Worden, J. R.: A joint data record of tropospheric ozone from Aura-TES and MetOpIASI, Atmos. Chem. Phys., 16, 10229-10239, doi:10.5194/acp16-10229-2016, 2016.

Ott, L. E., Duncan, B. N., Thompson, A. M., Diskin, G., Fasnacht, Z., Langford, A. O., Lin, M., Molod, A. M., Nielsen, J. E., Pusede, S. E., et al.: Frequency and impact of summertime stratospheric intrusions over Maryland during DISCOVER-AQ (2011): New evidence from NASA's GEOS-5 simulations, J. Geophys. Res.-Atmos., 121, 3687-3706, doi:10.1002/2015JD024052, 2016.

Park, R. J., Jacob, D. J., Field, B. D., Yantosca, R. M., and Chin, M.: Natural and transboundary pollution influences on sulfate-nitrate-ammonium aerosols in the United States: Implications for policy, J. Geophys. Res., 109, D15204, doi:10.1029/2003JD004473, 2004.

Parrington, M., Jones, D. B. A., Bowman, K. W., Horowitz, L. W., Thompson, A. M., Tarasick, D. W., and Witte, J. C.: Estimating the summertime tropospheric ozone distribution over North America through assimilation of observations from the Tropospheric Emission Spectrometer, J. Geophys. Res., 113, D18307, doi:10.1029/2007JD009341, 2008.

Parrington, M., Jones, D. B. A., Bowman, K. W., Thompson, A. M., Tarasick, D. W., Merrill, J., Oltmans, S. J., Leblanc, T., Witte, J. C., and Millet, D. B.: Impact of the assimilation of ozone from the Tropospheric Emission Spectrometer on surface ozone across North America, Geophys. Res. Lett., 36, L04802, doi:10.1029/2008GL036935, 2009.

Parrish, D. D., Millet, D. B., and Goldstein, A. H.: Increasing ozone in marine boundary layer inflow at the west coasts of North America and Europe, Atmos. Chem. Phys., 9, 1303-1323, doi:10.5194/acp-9-1303-2009, 2009.

Parrish, D. D., Aikin, K. C., Oltmans, S. J., Johnson, B. J., Ives, M., and Sweeny, C.: Impact of transported background ozone inflow on summertime air quality in a California ozone exceedance area, Atmos. Chem. Phys., 10, 10093-10109, doi:10.5194/acp10-10093-2010, 2010.

Parrish, D. D., Law, K. S., Staehelin, J., Derwent, R., Cooper, O. R., Tanimoto, H., Volz-Thomas, A., Gilge, S., Scheel, H.-E., Steinbacher, M., and Chan, E.: Long-term changes in lower tropospheric baseline ozone concentrations at northern mid-latitudes, Atmos. Chem. Phys., 12, 11485-11504, doi:10.5194/acp-1211485-2012, 2012.

Pierce, R. B., Schaack, T., Al-Saadi, J., Fairlie, T. D., Kittaka, C., Lingenfelser, G., Natarajan, M., Olson, J., Soja, A., Zapotocny, T., Lenzen, A., Stobie, J., Johnson, D., Avery, M., Sachse, G., Thompson, A. M., Cohen, R. C., Dibb, J., Crawford, J., Rault, D., Martin, R., Szykman, J., and Fishman, J.: Chemical data assimilation estimates of continental U.S. ozone and nitrogen budgets during the Intercontinental Chemical Transport Experiment-North America, J. Geophys. Res., 112, D12S21, doi:10.1029/2006JD007722, 2007.

Pierce, R. B., Al-Saadi, J., Kittaka, C., Schaack, T., Lenzen, A., Bowman, K., Szykman, J., Soja, A., Ryerson, T., Thompson, A. M., Bhartia, P., and Morris, G. A.: Impacts of background ozone production on Houston and Dallas, Texas, air quality during the Second Texas Air Quality Study field mission, J. Geophys. Res., 114, D00F09, doi:10.1029/2008JD011337, 2009. 
Pouliot, G., Denier van der Gon, H. A. C., Kuenen, J., Zhang, J., Moran, M. D., and Makar, P. A.: Analysis of the emission inventories and model-ready emission datasets of Europe and North America for phase 2 of the AQMEII project, Atmos. Environ., 115, 345-360, 2015.

Qu, Z., Henze, D. K., Capps, S. L., Wang, Y., Xu, X., Wang, J., and Keller, M.: Monthly top-down $\mathrm{NO}_{x}$ emissions for China (2005-2012): A hybrid inversion method and trend analysis, J. Geophys. Res.-Atmos., 122, doi:10.1002/2016JD025852, online first, 2017.

Quennehen, B., Raut, J.-C., Law, K. S., Daskalakis, N., Ancellet, G., Clerbaux, C., Kim, S.-W., Lund, M. T., Myhre, G., Olivié, D. J. L., Safieddine, S., Skeie, R. B., Thomas, J. L., Tsyro, S., Bazureau, A., Bellouin, N., Hu, M., Kanakidou, M., Klimont, Z., Kupiainen, K., Myriokefalitakis, S., Quaas, J., Rumbold, S. T., Schulz, M., Cherian, R., Shimizu, A., Wang, J., Yoon, S.-C., and Zhu, T.: Multi-model evaluation of short-lived pollutant distributions over east Asia during summer 2008, Atmos. Chem. Phys., 16, 10765-10792, doi:10.5194/acp-16-10765-2016, 2016.

Reidmiller, D. R., Fiore, A. M., Jaffe, D. A., Bergmann, D., Cuvelier, C., Dentener, F. J., Duncan, B. N., Folberth, G., Gauss, M., Gong, S., Hess, P., Jonson, J. E., Keating, T., Lupu, A., Marmer, E., Park, R., Schultz, M. G., Shindell, D. T., Szopa, S., Vivanco, M. G., Wild, O., and Zuber, A.: The influence of foreign vs. North American emissions on surface ozone in the US, Atmos. Chem. Phys., 9, 5027-5042, doi:10.5194/acp-9-5027-2009, 2009.

Rodgers, C. D.: Inverse Methods for Atmospheric Sounding: Theory and Practice, World Sci., Singapore, 2000.

Ryerson, T. B., Andrews, A. E., Angevine, W. M., Bates, T. S., Brock, C. A., Cairns, B., Cohen, R. C., Cooper, O. R., de Gouw, J. A., Fehsenfeld, F. C., Ferrare, R. A., Fischer, M. L., Flagan, R. C., Goldstein, A. H., Hair, J. W., Hardesty, R. M., Hostetler, C. A., Jimenez, J. L., Langford, A. O., McCauley, E., McKeen, S. A., Molina, L. T., Nenes, A., Oltmans, S. J., Parrish, D. D., Pederson, J. R., Pierce, R. B., Prather, K., Quinn, P. K., Seinfeld, J. H., Senff, C. J., Sorooshian, A., Stutz, J., Surratt, J. D., Trainer, M., Volkamer, R., Williams, E. J., and Wofsy, S. C.: The 2010 California Research at the Nexus of Air Quality and Climate Change (CalNex) field study, J. Geophys. Res., 118, 5830-5866, 2013.

Schere, K., Flemming, J., Vautard, R., Chemel, C., Colette, A., Hogrefe, C., Bessagnet, B., Meleux, F., Mathur, R., Roselle, S., Hu, R.-M., Sokhi, R. S., Rao, S. T., and Galmarini, S.: Trace gas/aerosol boundary concentrations and their impacts on continental-scale AQMEII modeling domains, Atmos. Environ., 53, 38-50, doi:10.1016/j.atmosenv.2011.09.043, 2012.

Shindell, D. T., Faluvegi, G., Koch, D. M., Schmidt, G. A., Unger, N., and Bauer, S. E.: Improved attribution of climate forcing to emissions, Science, 326, 716-718, doi:10.1126/science.1174760, 2009.

Shindell, D. T., Lamarque, J.-F., Schulz, M., Flanner, M., Jiao, C., Chin, M., Young, P. J., Lee, Y. H., Rotstayn, L., Mahowald, N., Milly, G., Faluvegi, G., Balkanski, Y., Collins, W. J., Conley, A. J., Dalsoren, S., Easter, R., Ghan, S., Horowitz, L., Liu, X., Myhre, G., Nagashima, T., Naik, V., Rumbold, S. T., Skeie, R., Sudo, K., Szopa, S., Takemura, T., Voulgarakis, A., Yoon, J.-H., and Lo, F.: Radiative forcing in the ACCMIP historical and future climate simulations, Atmos. Chem. Phys., 13, 2939-2974, doi:10.5194/acp-13-2939-2013, 2013.
Simpson, D., Benedictow, A., Berge, H., Bergström, R., Emberson, L. D., Fagerli, H., Flechard, C. R., Hayman, G. D., Gauss, M., Jonson, J. E., Jenkin, M. E., Nyíri, A., Richter, C., Semeena, V. S., Tsyro, S., Tuovinen, J.-P., Valdebenito, Á., and Wind, P.: The EMEP MSC-W chemical transport model - technical description, Atmos. Chem. Phys., 12, 7825-7865, doi:10.5194/acp-127825-2012, 2012.

Sindelarova, K., Granier, C., Bouarar, I., Guenther, A., Tilmes, S., Stavrakou, T., Müller, J.-F., Kuhn, U., Stefani, P., and Knorr, W.: Global data set of biogenic VOC emissions calculated by the MEGAN model over the last 30 years, Atmos. Chem. Phys., 14, 9317-9341, doi:10.5194/acp-14-9317-2014, 2014.

Skamarock, W. C., Klemp, J. B., Dudhia, J., Gill, D., Barker, D. M., Wang, W., and Powers, J. G.: A description of the Advanced Research WRF version 3, available at: http://www2.mmm.ucar. edu/wrf/users/docs/arw_v3.pdf (last access: April 2017), 2008.

Smith, K. R., Jerrett, M., Anderson, H. R., Burnett, R. T., Stone, V., Derwent, R., Atkinson, R. W., Cohen, A., Shonkoff, S. B., Krewski, D., Pope III, C. A., Thun, M. J., and Thurston, G.: Public health benefits of strategies to reduce greenhouse-gas emissions: health implications of short-lived greenhouse pollutants, Lancet, 374, 2091-2103, doi:10.1016/S0140-6736(09)61716-5, 2009.

Solazzo, E., Bianconi, R., Vautard, R., Appel, K. W., Moran, M. D., Hogrefe, C., Bessagnet, B., Brandt, J., Christensen, J. H., Chemel, C., Coll, I., van der Gon, H. D., Ferreira, J., Forkel, R., Francis, X. V., Grell, G., Grossi, P., Hansen, A. B., Jeričević, A., Kraljević, L., Miranda, A. I., Nopmongcol, U., Pirovano, G., Prank, M., Riccio, A., Sartelet, K. N., Schaap, M., Silver, J. D., Sokhi, R. S., Vira, J., Werhahn, J., Wolke, R., Yarwood, G., Zhang, J., Rao, S. T., and Galmarini, S.: Model evaluation and ensemble modelling of surface-level ozone in Europe and North America in the context of AQMEII, Atmos. Environ., 53, 60-74, doi:10.1016/j.atmosenv.2012.01.003, 2012.

Søvde, O. A., Prather, M. J., Isaksen, I. S. A., Berntsen, T. K., Stordal, F., Zhu, X., Holmes, C. D., and Hsu, J.: The chemical transport model Oslo CTM3, Geosci. Model Dev., 5, 1441-1469, doi:10.5194/gmd-5-1441-2012, 2012.

Sudo, K., Takahashi, M., Kurokawa, J., and Akimoto, H.: Chaser: A global chemical model of the troposphere, 1. Model description, J. Geophys. Res., 107, 4339, doi:10.1029/2001JD001113, 2002.

Stevenson, D. S., Dentener, F. J., Schultz, M. G., Ellingsen, K., van Noije, T. P. C., Wild, O., Zeng, G., Amann, M., Atherton, C. S., Bell, N., Bergmann, D. J., Bey, I., Butler, T., Cofala, J., Collins, W. J., Derwent, R. G., Doherty, R. M., Drevet, J., Eskes, H. J., Fiore, A. M., Gauss, M., Hauglustaine, D. A., Horowitz, L. W., Isaksen, I. S. A., Krol, M. C., Lamarque, J.-F., Lawrence, M. G., Montanaro, V., Müller, J.-F., Pitari, G., Prather, M. J., Pyle, J. A., Rast, S., Rodriguez, J. M., Sanderson, M. G., Savage, N. H., Shindell, D. T., Strahan, S. E., Sudo, K., and Szopa, S.: Multimodel ensemble simulations of present-day and near-future tropospheric ozone, J. Geophys. Res., 111, D08301, doi:10.1029/2005JD006338, 2006.

Stevenson, D. S., Young, P. J., Naik, V., Lamarque, J.-F., Shindell, D. T., Voulgarakis, A., Skeie, R. B., Dalsoren, S. B., Myhre, G., Berntsen, T. K., Folberth, G. A., Rumbold, S. T., Collins, W. J., MacKenzie, I. A., Doherty, R. M., Zeng, G., van Noije, T. P. C., Strunk, A., Bergmann, D., Cameron-Smith, P., Plummer, D. A., Strode, S. A., Horowitz, L., Lee, Y. H., Szopa, S., Sudo, K., Na- 
gashima, T., Josse, B., Cionni, I., Righi, M., Eyring, V., Conley, A., Bowman, K. W., Wild, O., and Archibald, A.: Tropospheric ozone changes, radiative forcing and attribution to emissions in the Atmospheric Chemistry and Climate Model Intercomparison Project (ACCMIP), Atmos. Chem. Phys., 13, 3063-3085, doi:10.5194/acp-13-3063-2013, 2013.

Susaya, J., Kim, K.-H., Shon, Z.-H., and Brown, R. J.: Demonstration of long-term increases in tropospheric $\mathrm{O}_{3}$ levels: Causes and potential impacts, Chemosphere, 92, 1520-1528, 2013.

Task Force on Hemispheric Transport of Air Pollution (HTAP): 2010 Final Assessment report, Part A: Ozone and particulate matter, available at: http://www.htap.org/publications/2010_ report/2010_Final_Report/HTAP\%202010\%20Part\%20A\% 20110407.pdf (last acccess: April 2017), 2010.

Tilmes, S., Lamarque, J.-F., Emmons, L. K., Kinnison, D. E., Marsh, D., Garcia, R. R., Smith, A. K., Neely, R. R., Conley, A., Vitt, F., Val Martin, M., Tanimoto, H., Simpson, I., Blake, D. R., and Blake, N.: Representation of the Community Earth System Model (CESM1) CAM4-chem within the ChemistryClimate Model Initiative (CCMI), Geosci. Model Dev., 9, $1853-$ 1890, doi:10.5194/gmd-9-1853-2016, 2016.

Travis, K. R., Jacob, D. J., Fisher, J. A., Kim, P. S., Marais, E. A., Zhu, L., Yu, K., Miller, C. C., Yantosca, R. M., Sulprizio, M. P., Thompson, A. M., Wennberg, P. O., Crounse, J. D., St. Clair, J. M., Cohen, R. C., Laughner, J. L., Dibb, J. E., Hall, S. R., Ullmann, K., Wolfe, G. M., Pollack, I. B., Peischl, J., Neuman, J. A., and Zhou, X.: Why do models overestimate surface ozone in the Southeast United States?, Atmos. Chem. Phys., 16, 1356113577, doi:10.5194/acp-16-13561-2016, 2016.

United Nations Environment Programme and World Meteorological Organization: Integrated Assessment of Black Carbon and Tropospheric Ozone: Summary for Decision Makers, available at: https://wedocs.unep.org/rest/bitstreams/12809/retrieve (last access: April 2017), 2011.

US EPA: Implementation of the 2015 Primary Ozone NAAQS: Issues Associated with Background Ozone White Paper for Discussion, available at: https://www.epa.gov/sites/production/ files/2016-03/documents/whitepaper-bgo3-final.pdf (last access: March 2017), 2016a.

US EPA: High level summary of background ozone workshop, available at: https://www.epa.gov/sites/production/files/2016-03/ documents/bgo3-high-level-summary.pdf (last access: March 2017), 2016b.

van der Werf, G. R., Randerson, J. T., Giglio, L., Collatz, G. J., Mu, M., Kasibhatla, P. S., Morton, D. C., DeFries, R. S., Jin, Y., and van Leeuwen, T. T.: Global fire emissions and the contribution of deforestation, savanna, forest, agricultural, and peat fires (19972009), Atmos. Chem. Phys., 10, 11707-11735, doi:10.5194/acp10-11707-2010, 2010.

van Noije, T. P. C., Eskes, H. J., Dentener, F. J., Stevenson, D. S., Ellingsen, K., Schultz, M. G., Wild, O., Amann, M., Atherton, C. S., Bergmann, D. J., Bey, I., Boersma, K. F., Butler, T., Cofala, J., Drevet, J., Fiore, A. M., Gauss, M., Hauglustaine, D. A., Horowitz, L. W., Isaksen, I. S. A., Krol, M. C., Lamarque, J.-F., Lawrence, M. G., Martin, R. V., Montanaro, V., Müller, J.F., Pitari, G., Prather, M. J., Pyle, J. A., Richter, A., Rodriguez, J. M., Savage, N. H., Strahan, S. E., Sudo, K., Szopa, S., and van Roozendael, M.: Multi-model ensemble simulations of tropospheric $\mathrm{NO}_{2}$ compared with GOME retrievals for the year
2000, Atmos. Chem. Phys., 6, 2943-2979, doi:10.5194/acp-62943-2006, 2006.

Verstraeten, W. W., Boersma, K. F., Zörner, J., Allaart, M. A. F., Bowman, K. W., and Worden, J. R.: Validation of six years of TES tropospheric ozone retrievals with ozonesonde measurements: implications for spatial patterns and temporal stability in the bias, Atmos. Meas. Tech., 6, 1413-1423, doi:10.5194/amt-61413-2013, 2013.

Verstraeten, W. W., Neu, J. L., Williams, J. E., Bowman, K. W., Worden, J. R., and Boersma, K. F.: Rapid increases in tropospheric ozone production and export from China, Nat. Geosci., 8, 690-695, doi:10.1038/ngeo2493, 2015.

Wang, H., Jacob, D. J., Sager, P. L., Streets, D. G., Park, R. J., Gilliland, A. B., and van Donkelaar, A.: Surface ozone background in the United States: Canadian and Mexican pollution influences, Atmos. Environ., 43, 1310-1319, doi:10.1016/j.atmosenv.2008.11.036, 2009.

Wang, Y., Konopka, P., Liu, Y., Chen, H., Müller, R., Plöger, F., Riese, M., Cai, Z., and Lü, D.: Tropospheric ozone trend over Beijing from 2002-2010: ozonesonde measurements and modeling analysis, Atmos. Chem. Phys., 12, 8389-8399, doi:10.5194/acp-12-8389-2012, 2012.

Warneke, C., deGouw, J. A., Holloway, J. S., Peischl, J., Ryerson, T. B., Atlas, E., Blake, D., Trainer, M., and Parrish, D. D.: Multiyear trends in volatile organic compounds in Los Angeles, California: Five decades of decreasing emissions, J. Geophys. Res., 117, D00V17, doi:10.1029/2012JD017899, 2012.

Warner, J. X., McCourt Comer, M., Barnet, C. D., McMillan, W. W., Wolf, W., Maddy, E., and Sachse, G.: A comparison of satellite tropospheric carbon monoxide measurements from AIRS and MOPITT during INTEX-A, J. Geophys. Res., 112, D12S17, doi:10.1029/2006JD007925, 2007.

Wiedinmyer, C., Akagi, S. K., Yokelson, R. J., Emmons, L. K., AlSaadi, J. A., Orlando, J. J., and Soja, A. J.: The Fire INventory from NCAR (FINN): a high resolution global model to estimate the emissions from open burning, Geosci. Model Dev., 4, 625641, doi:10.5194/gmd-4-625-2011, 2011.

Wigder, N. L., Jaffe, D. A., Herron-Thorpe, F. L., and Vaughan, J. K.: Influence of daily variations in baseline ozone on urban air quality in the United States Pacific Northwest, J. Geophys. Res., 118, 3343-3354, doi:10.1029/2012JD018738, 2013.

Wild, O., Fiore, A. M., Shindell, D. T., Doherty, R. M., Collins, W. J., Dentener, F. J., Schultz, M. G., Gong, S., MacKenzie, I. A., Zeng, G., Hess, P., Duncan, B. N., Bergmann, D. J., Szopa, S., Jonson, J. E., Keating, T. J., and Zuber, A.: Modelling future changes in surface ozone: a parameterized approach, Atmos. Chem. Phys., 12, 2037-2054, doi:10.5194/acp-12-20372012, 2012.

Wu, S., Duncan, B. N., Jacob, D. J., Fiore, A. M., and Wild, O.: Chemical nonlinearities in relating intercontinental ozone pollution to anthropogenic emissions, Geophys. Res. Lett., 36, L05806, doi:10.1029/2008GL036607, 2009.

Yarwood, G., Rao, S., Yocke, M., and Whitten, G.: Updates to the carbon bond chemical mechanism: CB05. Final report to the US EPA, EPA Report Number: RT-0400675, 2005.

Zhang, L., Jacob, D. J., Boersma, K. F., Jaffe, D. A., Olson, J. R., Bowman, K. W., Worden, J. R., Thompson, A. M., Avery, M. A., Cohen, R. C., Dibb, J. E., Flock, F. M., Fuelberg, H. E., Huey, L. G., McMillan, W. W., Singh, H. B., and Weinheimer, 
A. J.: Transpacific transport of ozone pollution and the effect of recent Asian emission increases on air quality in North America: an integrated analysis using satellite, aircraft, ozonesonde, and surface observations, Atmos. Chem. Phys., 8, 6117-6136, doi:10.5194/acp-8-6117-2008, 2008.

Zhang, L., Jacob, D. J., Kopacz, M., Henze, D. K., Singh, K., and Jaffe, D. A.: Intercontinental source attribution of ozone pollution at western U.S. sites using an adjoint method, Geophys. Res. Lett., 36, L11810, doi:10.1029/2009GL037950, 2009.

Zhang, L., Jacob, D. J., Downey, N. V., Wood, D. A., Blewitt, D., Carouge, C. C., van Donkelaar, A., Jones, D. B. A., Murray, L. T., and Wang, Y.: Improved estimate of the policy-relevant background ozone in the United States using the GEOS-Chem global model with $1 / 2^{\circ} \times 2 / 3^{\circ}$ horizontal resolution over North America, Atmos. Environ., 45, 6769-6776, doi:10.1016/j.atmosenv.2011.07.054, 2011.

Zhang, Q., Yuan, B., Shao, M., Wang, X., Lu, S., Lu, K., Wang, M., Chen, L., Chang, C.-C., and Liu, S. C.: Variations of ground-level $\mathrm{O}_{3}$ and its precursors in Beijing in summertime between 2005 and 2011, Atmos. Chem. Phys., 14, 6089-6101, doi:10.5194/acp-14-6089-2014, 2014.
Zhang, Y., Chen, Y., Sarwar, G., and Schere, K.: Impact of gasphase mechanisms on Weather Research Forecasting Model with Chemistry (WRF/Chem) predictions: Mechanism implementation and comparative evaluation, J. Geophys. Res., 117, D01301, doi:10.1029/2011JD015775, 2012.

Zoogman, P., Liu, X., Suleiman, R. M., Pennington, W. F., Flittner, D. E., Al-Saadi, J. A., Hilton, B. B., Nicks, D. K., Newchurch, M. J., Carr, J. L., Janz, S. J., Andraschko, M. R., Arola, A., Baker, B. D., Canova, B. P., Chan Miller, C., Cohen, R. C., Davis, J. E., Dussault, M. E., Edwards, D. P., Fishman, J., Ghulam, A., González Abad, G., Grutter, M., Herman, J. R., Houck, J., Jacob, D. J., Joiner, J., Kerridge, B. J., Kim, J., Krotkov, N. A., Lamsal, L., Li, C., Lindfors, A., Martin, R. V., McElroy, C. T., McLinden, C., Natraj, V., Neil, D. O., Nowlan, C. R., OSullivan, E. J., Palmer, P. I., Pierce, R. B., Pippin, M. R., Saiz-Lopez, A., Spurr, R. J. D., Szykman, J. J., Torres, O., Veefkind, J. P., Veihelmann, B., Wang, H., Wang, J., and Chance, K.: Tropospheric emissions: Monitoring of pollution (TEMPO), J. Quant. Spectrosc. Ra., 186, 17-39, doi:10.1016/j.jqsrt.2016.05.008, 2017. 